, 


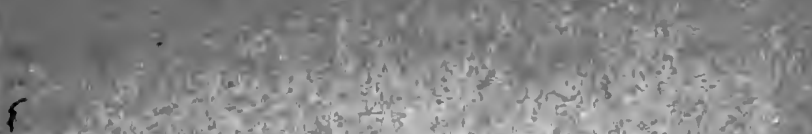

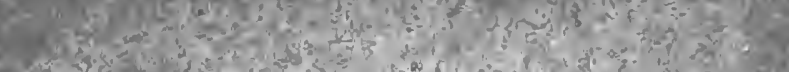

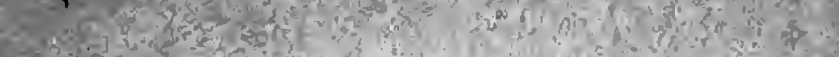

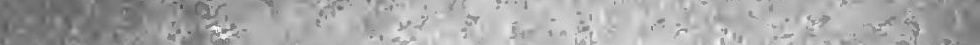

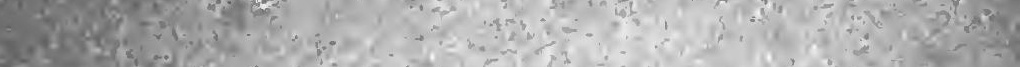
1)

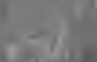

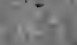

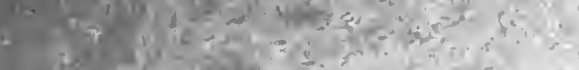

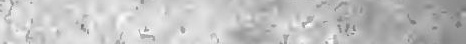

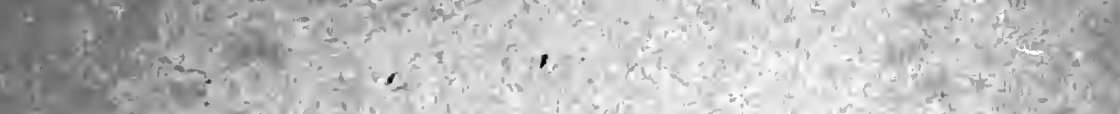



THE

SOCIAL CONTRACT 


\section{BI THE SAME AUTHOR. \\ LIBERTY AND PROGRESS.}

8vo. 9s. net.

Part I. The Employed.

Part II. The Principles of Employment.

Part III. OUR Underpaid ANd UNemployed.

LONGMANS, GREEN \& CO., LONDON, NEW YORK, BOMBAY \& CALCUTTA. 


\section{EсPF \\ $D 2692$ so}

\section{THE}

\section{SOCIAL CONTRACT}

MORE PARTICULARLY IN RELATION TO

TAXATION

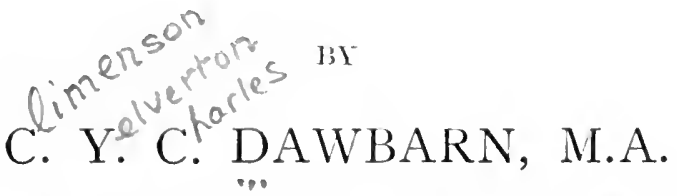

Author of " Oneiros : or Some Questions of the Day,"

"Employers' Liability," "Liberty and Progress," etc., etc.

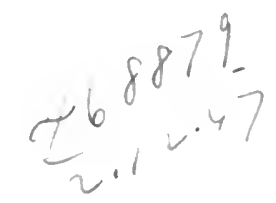

LONGMANS, GREEN AND CO.

39 PATERNOSTER ROW, LONDON

NEW YORK, BOMBAY AND CALCUTTA

I 9 IO 
1. 1. Digitized by the Internet Archive in 2007 with funding from (i) is Microsoft Corporation 


\section{PREFACE}

THE following few pages are practically the complement of my larger volume "Liberty and Progress," in which I took as my premises that liberty was the end of "Individualism," and the just payment for services rendered its essential condition. Services rendered divide into two great classes: those we render and receive as individuals, and those we render and receive acting collectively. Payment for both ought to be equally just. With the former I have somewhat lengthily dealt in my previous book, the latter forms the subject of the present enquiry. As will be easily understood, there is no little common ground between the two, and in order to avoid reference from one book to another, and to make the present argument complete in itself, I have repeated where necessary the matter there used. This more particularly refers to property, its origin, nature and justification, and if it somewhat exceeds what I first anticipated I must for such repetition ask the indulgence of former readers. No doubt the subject of payment for collective services received, otherwise taxation, is one of the greatest importance in the whole range of economic science. At the same time, when engaged in 
writing my former book its principles seemed to be so well and generally accepted that beyond a few stray notes I hardly gave it further attention. But of a sudden it has loomed large on the horizon of political life, and therefore once more it seems well that old principles should be restated and old teaching reinforced. As I have also previously said, I make little claim to either originality or novelty. My humbler aim has been to seek out what our wisest have thought, and to find in their writings guidance in our present conditions.

And here one word of explanation. The following pages are not intended as a complete manual on the subject of taxation. Rather I regard the conclusions of political economy as the tools with which those dealing with social subjects should work. The province of the political economist is to ascertain and discover the laws governing society, and to determine their effect. On the other hand it may well be that a first-rate statesman will be far sounder in his practical application of principles to existing conditions than the profoundest theorist. One bases his conclusions on hypothetical assumptions, the other is concerned with laws only so far as they are in actual relation to living organisms. Thus, for example, John Stuart Mill assumes perfect free competition and the complete transferability of capital (a), neither of which conditions exists, and

(a) Seligman's Taxation, p. 158. 
on these assumptions builds up his whole superstructure. As a practical treatise, this lessens the value of his conclusions as an everyday guide, and might possibly mislead some of his disciples who were not cognisant of his premises. But none the less the true statesman sees the law and knows the law, and his mastery of facts is based on knowledge, not on ignorance of principles immutable as the globe itself. Like the great master of harmony, he alone dare break the law who by life-long study has learnt how to keep it.

Here another important matter to be remembered is that whilst Individualism is the basis of modern society, and as such is taken as the premises of the following argument, yet it is not the necessary or only theoretical basis of society.

This is well to be observed, for as Oliver Wendell Holmes neatly says as regards the kindred subject of conversation, "What spoil good talks more than anything else are long arguments on special points between people who differ on the fundamental principles upon which these points depend." Thus every man only demands, only insists upon, justice. Fiat justitia ruat coelum is a phrase generally acclaimed. But what is justice?

The determination of rights.

And what are rights?

The resultants of first principles.

And what are first principles?

What we quarrel over, and here the curious fact 
is, that the more ignorant the debater the greater his confidence that he, and he only, is inspired with knowledge of natural right or natural justice $(b)$. But the more one ponders on the subject, the more impenetrable the mystery with which it is enveloped seems to become.

But here it is impossible for us to enter into a discussion of the relative merits of other possible systems, of the fundamental principles of Wendell Holmes, and we must rigidly limit ourselves to trying to determine what is just on the basis of things as they now are. In this we shall but follow the lead of innumerable thinkers, judges and law makers who can never be brought to agree that things are right or as intended, and yet can most faithfully and impartially do justice between man and man on such assumption. In this spirit let us approach the subject, and so far as we desire the regeneration of society, so far shall we the more effectually secure our end if we satisfy our fellows our desire is to be just.

To see things as they are. To whom is it given?

(b) "There is no reasoning with fanatics armed with natural rights, which each one understands as he pleases and applies as he sees fit; of which nothing can be yielded nor retrenched; which are inflexible at the same time that they are unintelligible; which are consecrated as dogmas from which it is a crime to vary." - Benthan, Principles of Legislation, p. 85 .

"One thing in the midst of all this confusion is but too plain. They know not of what they are talking under the name of natural rights, and yet they would have them imprescriptible."-Bentham, Vol. II., p. 498. 
To the immortals alone. It is the end of philosophy and the beginning of wisdom. Then when we see things as they are, we shall know justice as it is.

In the meantime let our motto be work! study and enquire! and if it be only one step at a time, do not let us repine so long as that step be forward. All change is not reform, all alterations are not progress, and though to have done something great and glorious may be very magnificent, yet an inch in the way is worth a mile in the clouds.

\section{Y. C. DAWBARN.}

\section{Note.}

The following is one of the notes on taxation referred to, and as it briefly epitomizes the present argument it may be of service here :-

"On what principle taxes should be contributed by members of a community is a matter on which opinions vary. The different schools are not unfairly summarised by Mill as follows :- ' How many, again, and how irreconcileable, are the standards of justice to which reference is made in discussing the repartition of taxation. One opinion is that payment to the State should be in numerical proportion to pecuniary means; others think that justice dictates what they term graduated taxation-taking a higher percentage from those who have more to spare. In point of natural justice a strong case might be made for disregarding means altogether and taking the same absolute sum (whenever it could be got) from every one; as the subseribers to a mess or to a club all pay the same sum for the same privileges, whether they can all equally afford it or not.' "-J. S. Mill, Utilitarianism, p. 8 I $^{\text {. }}$

"The true underlying principle-the converse of the one under discussion-is payment for services received. A nation 
is but an aggregate of people living together who give services and receive services to and from one another, and that society is most perfect where such services are most justly valued. Individuals give services, and should be justly paid; they receive services, and should justly pay. Living together involves a certain sacrifice of individual liberty, and on the whole it is not unreasonable that, so far as necessary, the minority should fall in with the wishes of the majority. But this does not alter the fundamental principle of contribution to the general purse to which we have referred. Each should pay in full for what he receives; but, having so paid, his fellows have no further claim upon his purse. How such quota should be determined demands a lengthy inquiry; but once determined, it should be impartially collected from all. It is not open on the grounds of convenience to make any pay more than their just share. The principle of convenience is only to give effect to, and not encroach upon, the principle of just contribution. Nor is it open to try to right a wrong by taxation. If a man acquires wrongly, the duty is to prevent the acquisition in its entirety. To take from all of a class because some are bad is to make the good suffer for the evil. If the good have already contributed their just share, and more is taken from them, they are no less robbed because it is done by their fellows acting collectively than if it had been done by a few acting independently." 


\section{CON'TEN'TS}

CHAPTER

I. The Contract in Theory

Individualism and Liberty-The Rise of DemocracyIts effective Expression-Its Rights and Limitations.

II. Liberty AND its Modification

Liberty in relation to Young Persons and Workpeople. Note: Women and the Franchise.

III. Collective Obligations

Matters of (a) Obligation; (b) Quasi-obligation arising out of the Rights of Young People; (c) No Obligation more particularly as affecting the Unemployed.

Note: Taxation as a Remedy for Abuses.

IV. The Basis of Taxation

Payment for Services received-Theory of "Afford" considered-Adam Smith's "Equality" Rule--The "Faculty" Basis.

V. "SERvices ReceIved"-TiIeIR APPRAISEMENT $\ldots 44$

Of a "Poll Tax"-Of Financial Benefits received.

VI. Contribution by " Earned Ixcones" 48

Proportional Taxation-Case for Progressive TaxationCapital as a Factor-" Margin of Profit," Arguments against.

VII. Contribution by “UNearned Incomes," ANI Hereon of Property in General

Property the Creation of Iaw only--Its Nature and Justification-Capital the Result of Saving-Our vast Inheritance.

Note: Other Sanctions of Property.

VIII. The SAME Continued ... 64

Our National Income-Its Indebtedness to PropertyThe Share taken by Labour, by Capital lent on Hire-The Receipts of Capital regulated by Competition of Owners to have it used.

Note: The Socialist Attitude. 
IX. Contribution By “Unearned Incomes"-Conditions TO BE OBSERVED... $\quad \ldots \quad \ldots . \quad \ldots \quad \ldots$

Accumulation not to be checked-Nor Capital driven abroad to find Investment-Equality of TreatmentServices received by Owners of Property proportional.

X. Transmission of Property at Death, and Relative Contribution BY EARNed and Unearned Incomes

Charges for carrying out Wishes of Owners-Death Duties and the Inequality of Individualism-Factors to be considered-Large Fortunes and Compulsory Saving-Taxation of Capital inexpedient-Conclusion as to relative Contribution.

XI. Property in certain Forms

Monopoly in Capital ; in Land-Land as the Subject of Property-Desirable to favour Home InvestmentsThe Rebuilding of our Cities-Necessity for outside Money to be brought in-The Incidents of Land from income-yielding Point of View same as those of other Property.

Note : Recent Legislative Proposals.

XII. As to Special Trades

Monopoly in Sale of Intoxicants-Increase in Cost borne by Consumer.

Note: The Working of Mr. Balfour's Act-“'Levelling up" - Sweated Industries.

XIII. The Moyopoly of Patents and of Trusts $\ldots 108$

Why exclusive Rights granted by Patents-If Individualism does not kill Trusts, Trusts will kill Individualism.

XIV. The Collection of the Revenue-Some General $\begin{array}{lllll}\text { Considerations } & \ldots & \ldots & \ldots & \ldots\end{array}$

Convenience subsidiary to "Equality"-Poll Tax raised by general Impost-The Importance of Certainty in our Contractual Relations-Theoretical Perfection and Practical Injustice-The re-making of Contracts by Law.

XV. The Collection of the Revenue-Sone Practical

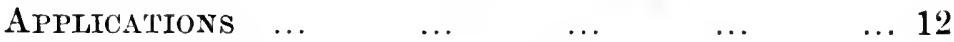

No'TE: Certain aspects of "Tariff Reform."

XVI. Taxation in its more Practical Aspect $\ldots . \quad \ldots 127$

Items of Revenue-Benefits of Simplification.

XVII. Conclusion

Seriousness of Reckless Expenditure. 


\section{THE SOCIAL CONTRACT}

\section{CHAPTER I.}

THE CONTRACT IN 'THEORY.

History furnishes us with few examples where the basis of the social contract in civilized communities has been other than Individualism. Whether it is the best or the wisest is not for us now to determine. Possibly with man self-centred as he is, it may be the necessary basis. But into this, again, we need not enquire. It is sufficient for our present enquiry that it is the basis.

And here we ask, what is the underlying principle of Individualism? It is simply the logical development of the one idea, liberty. And what do we understand by the word liberty? The free, full and unfettered right to do exactly as we please, without regard to anything but our own unbridled desires. To think for ourselves, act for ourselves, and order our own lives in our own way; this is our ideal of life, this is liberty. But as such liberty on our part finds equal right to equal liberty in every one else, it means that in its unlimited development perfect liberty becomes perfect license; in other words, becomes perfect tyranny - the domi- 
nation of the strong over the weak. Hence we willingly agree that some of our personal liberty should be curtailed if that of others be similarly restrained; and in the result the liberty we desire is, that every man should have the greatest possible freedom of action consistent with the like right of every one else to the same, and that each should have the utmost liberty in ordering his life consistent with his not injuring anyone else. And this conception of liberty, we see, involves a nice balancing of rights between individuals, a considerable amount of give and take, and no little deference to the wishes of other people. Perfect freedom we do not profess to claim or confer. All freedom must be limited, and it is limited by mutual agreement, or as we term it, by law. So in the main we esteem a law as good or bad exactly so far as it necessarily or unnecessarily curtails our freedom of action. Naturally, when we have over forty millions of people crowded into these small islands, the laws necessary to secure such liberty become extremely difficult and complicated. In a simpler state of society many things lawful and desirable might be possible which would be disastrous if introduced under present conditions. We cannot even feed ourselves; our raw materials are gathered from the four quarters of the globe; our wants are supplied by every nation under the sun; we enjoy an abundance represented by the fabulous amount of almost two thousand million pounds a year; whilst, left to our own resources or reduced to an elemental condition of society, our days as a nation 
would be ended. Only by organization of the highest order is it possible to secure a fair return for labour and relieve us all from one unending round of unremitting toil. It is therefore unprofitable for us to appeal to the rude ages of man as a guide to solving the problems of the hour. Return to these would mean the starvation and destruction of all but the strong, and a return to primitive life would be a return to disorder and anarchy. In fact, to-day there is no piece of machinery in the world one-half so complex as our social organization. As in a watch you cannot injure the smallest wheel without the whole suffering, and a blacksmith repairing a chronometer would have a delicate touch compared with that of some of our political mechanicians, so in society, you cannot alter one interest without the whole being discrganized.

To return to our simile, the balance wheel in a watch is no more essential to it than is the nice balance that must be maintained between contending interests in civilized communities. To secure this is the end of collective action. We agree what is the maximum liberty we can permit to one another, and we combine to ensure that no one shall overstep the bounds thus laid down. Then the more unanimous such collective action, and the more perfect the principles on which it is founded, the happier and more perfect is the condition of every one who goes to make up the whole. Much of the misery of the world is due to insufficient knowledge of principles in the first place, and 
power, moral or physical, to enforce them in the second. The two are needed in combination. Power without principles becomes tyranny, and principles without power are ignored.

To-day, amongst most nations, the power of the whole acting collectively is overwhelming. Even a Rockefeller with his hundred millions dare not challenge it, and to do so would be to court instant annihilation. But it has not always been so. In ancient times we find the chief satisfaction of a vast fortune was that it enabled its possessor to maintain an army and defy or subjugate his fellows. The history of the development of this collective action would be a fascinating study. In our own country, for example, we find in the early days of barbarism the same love of liberty as now prevails. But then it knew no bounds or measure, and the perfect freedom which entitled me to slay another and possess myself of his goods, was met by his equally perfect right to slay or despoil me if he should prove the stronger. For the man powerful in his own right arm these were heroic times; might was right, and unhappy the weakling who had no one to depend upon but himself. The quarry of every hawk, he had only one resourceto seek the protection of some great warrior willing to afford it. Hence the origin of many of our sovereign and noble families. Men helpless by themselves sought to become retainers of those who could or would assure them a measure of security. When this alliance was cemented by kinship and mutual services it became very real indeed, and 
loyalty and affection were often added to the bond of interest. As units, all but the very strongest were at the mercy of the first robber horde who cared to destroy them, and gladly they recognized as master the man who gave them security of life and possessions. His might was their right. Without him their lives were not worth a day's purchase, and a sentence of banishment was a sentence of death. These old days have passed away, but traces of the old affectionate terms thus established between lord and retainer are still to be found. With much genuine mutual pride both refer to relations that have existed between them for many generations. It is one of the precious survivals in modern life.

The transition to kingly supremacy was practically brought about by the Wars of the Roses. The power of individual barons to defy the rest of the kingaiom passed away, and a great advance was made on the road of enlightened democracy. Apparently the king acted of his own motion, but it was an important step to making the collective action of the whole omnipotent. The survival of feudal notions sometimes brought about false positions, but the virtual power of the monarch was the power of the many that supported him. So old methods for the defence of the kingdom gave way to new. It had been the practice for the lords and barons to furnish supplies in kind according to their estates, whilst their followers had to give their personal services in the field for a certain number of weeks in the year. As war became more com- 
plicated, money payments were substituted for such services, and the men were as pleased to be released from their attendance as their lord was to be relieved of onerous and uncertain duties. They paid the money, and the king undertook the maintenance of the kingdom. Thus, Hobbes in his "Leviathan" regards taxes as "wages due" to the sovereign power for protection and security $(a)$. By 1692 these "wages" had taken a fairly definite form. In that year an Act was passed in which a tax of $4 s$. in the pound was imposed on every class of income except that of naval and military officers. As a pretty exact prototype of our modern income and property tax it is interesting. By sect. 2 a tax of $4 \mathrm{~s}$. in the pound was levied on every person having an income from any estate in moneys, debts, wares, chattels, or other personal estate; by sect. 3 on all persons having an income from any employment of profit (saving as to military and naval officers as mentioned), and by sect. 4 a similar tax was to be paid by all having an income from manors, messuages, lands, tenements, quarries, mines, tithes, tolls, \&c. $(b)$.

Again, passing to modern times we see this power of collective action in its fullest development. To it

(a) Morley's Universal Library, p. 158.

(b) The taxes on movables begin with the Saladin tithe (Henry II.). The declaration was in form left to the conscience of the taxpayer (the sanction being excommunication), but if any one was suspected of giving too little, the secular power appointed a jury to assess the amount. The Saladin tithe shows in many respects the rudiments of the modern income tax.-Nicholson, Prin. Pol. Ec., 3, 260. 
all other authorities have given place, and now all orders and institutions but exist to give it effective expression. And with us more than ever is it essential that such collective action shall be based on sound principles; more than ever is it essential that we determine what is just between one man and another, so that what we term rights may always have behind them the sanction of an overwhelming majority of the nation. And here it must equally be never forgotten that the end of such collective action is as ever the securing to us the utmost liberty compatible with that of our neighbours $(c)$.

To make effective such action we first find it essential to have some one whom we respect and venerate to act officially as the representative of us all. In our dealings with foreign powers it is essential to have some head who ean speak in the name of the nation. So it is our pride to have one in whom we find an exemplification of all we most prize in our race and its proud story, one in whom

(c) It is no less important in a democratic than in any other government that all tendency on the part of public authorities to stretch their interference and assume a power of any sort that can readily be dispensed with should be regarded with umremitting jealousy. Perhaps this is even more important in a democracy than in any other form of political society, because when public opinion is sovereign, an individual who is oppressed by the sovereign does not as in most other state of things, find a rival power to which he can appeal for relief or at all events for sympathy.—IFill, Pol. Ec., Bk. V. c. xi. \$3. 
we recognize the embodiment of those grand traditions we love to associate with our greatest in the land, and one to whom in the last resort we can appeal as final arbitrator in disputes that might otherwise wreck the national constitution. So as regards any contribution that may be necessary to enable him to maintain with dignity his high office, we make it gladly, and we would feel it a slight on our majesty as a people if he were not able to bear his part proudly with the richest and noblest in the land.

Again, that this collective action may be satisfactorily put in operation it is necessary to have extensive administrative services, to the cost of which we also willingly subscribe our share. Then equally important is it that all matters of general interest shall be fully and adequately discussed. This we secure by our present representative Assembly, tempered by the revision of a Second Chamber. The present system which prevails is what we term government by party, and its end is to ensure that no new measure shall be enacted without the fullest deliberation. To secure this the fiction is that one party shall propose and the other criticise every new departure. But underlying this fiction is the profound principle that immediately any party takes office it shail that instant forget all sectional advantages and seek the national good alone. On any other conditions the party system would be intolerable, and one which no honourable man could support; so directly such conditions are broken no man can with propriety support his party further. Again, a further 
incident of our government by party is that whilst as a modus vivendi it is agreed that the will of the majority for the time being must prevail, yet underlying this agreement must be borne in mind that the object to be secured is the enforcement of wellestablished principles, and the enlargement, and not the restriction, of liberty. No majority, because a majority, is justified in trampling under foot the rights of others because in a minority, and the wantonly doing so is once more to assert the right of might, to court an appeal to vis major, and to violate that confidence between man and man so essential to our general prosperity. The foundation of society is good faith, but once admit that the strong may oppress the weak-and it is immaterial whether the strength be physical or merely that of numbers - and the days of barbarism, when each had to rely on himself for his own defence, are again in sight. . At times minorities have suffered from the despotism of autocrats; at times minorities have suffered from the tyranny of oligarchies; but no tyranny is more to be guarded against, no despotism more to be dreaded, than that of an unenlightened democracy guided by men defective in intelligence or limited in their breadth of view $(d)$. Anything is more tolerable than being dependent on the fickleness of a mob, and the surest road to the destruction of liberty is to make it dependent on the humour of a dema-

(d) Ignorance is more fatal than villainy. One causes useless and untold havoc, the other does no more injury than is necessary for its own advantage. 
gogue. Happily, as we shall see further on, the interests of all are so interwoven that there is little room in our country for any such, however plausible. Great reputations are founded on profound knowledge, and in the end it is only our truly wise who maintain a permanent influence in the councils of the nation. 


\section{CHAPTER II.}

\section{LIBERTY AND ITS MODIFICATION.}

LıвеRTY, to be an active principle in the spirit as well as the letter, must in some cases be taken with certain modifications. These in themselves are not necessarily repugnant to it, but rather amplifications necessary to render it more generally effective. Such a modification or limitation is that in favour of young persons, and those incapable of protecting their own interests. We do not allow these under cover of liberty to injure themselves, or do acts clearly to their own disadvantage.

When a man is wanting in that strength or intelligence which we take to be the portion of every average citizen, we rightly regard him as one to be protected against himself. So as regards parents, we do not recognize their unrestricted right to treat their children entirely as they please. A child's right to liberty may be in suspense, but otherwise neither differs from nor is less than that of an adult. It is deferred for its own benefit, not for that of its parents, and until such time as it can exercise it with advantage to itself the rest of us acting collectively are trustees to see that it is neither abridged nor abused. The question is, What would a child truly desire for itself if it were of sufficient understanding to judge? and to such 
implied desire it is our part to give effect. Thus, a parent who neglects his child-still more a parent who ill-treats it or abuses it, or even mistakenly acts injuriously to it-is correctly held to infringe the liberty of such child, and to warrant interference on its behalf. This limitation of the liberty of the parent is not therefore an unjustifiable infringement of his liberty, but is necessary to secure the more perfect liberty of the child. In the majority of cases the natural affection of the parents may be relied on to ensure the rights of the ehild, and there is no doubt that the lighest interests of the child are promoted by leaving the good and wise ones almost unlimited discretion; but where it is insufficient, there is not only the power, but a very certain duty as well, for us to interfere.

Similarly with reason we insist on sanitary conditions being observed in workshops, and on reasonable precaution being taken to secure the health, strength and safety of every worker. It is obviously not interfering with their liberty. It is only insisting upon what they themselves would liave done if they were in a position to make such demand. But here we nust be careful that we do not go too far, and try to give effect rather to what people ought to desire for themselves than what they actually do $(a)$.

(a) There alwilys will be cases on the line where any principle is involved. In law the fine judge is he who knows on what side given facts actually fall. Such is the case of home work. 
Some schools would extend the number and character of people to be presumed too helpless to take care of themselves. The arguments are so excellent that such class might be well enlarged to include the whole nation. A grandmotherly legislation interfering in every detail of daily life has much to recommend it, and it might be difficult to say which of us would not benefit by being subjected to a benevolent despotism. But it is a benefit which we, as a race, are detcrmined not to enjoy. Rather will we err on the side of liniting than of extending such class. As far as consistent with the rights of other people we will be our own masters, order our own lives, and act as we please; and we as bitterly resent the tyranny of a domestic legislative interference as that of any despot. We may be wrong as a nation in our attitude in this matter, but it finds its roots deep down in the roll of time, and now, as ever, if we have to pay a price for our independence we will pay it and he free.

\section{Note.}

How far women should be included in such class, and debarred from a voice in the collective affairs of the nation, is a matter on which there is considerable difference of opinion. Really it is difficult to say why they should be made an exception to the wholesome doctrine of no taxation without representation. "We want your money," the rest of us say; "then we should like a voice in its spending" is the very reasonable rejoinder. It is argued the majority of women do not want a vote. Is that a reason for disqualifying those who do? And as to the statement itself. In one of our 
colonies it seemed that few women desired the right, and it was only granted conditionally on their making personal application to be put on the register. It was then found there were few who did not apply to be enfranchised. The chivalry argument is also advanced, but it is rather inconsequent to talk of chivalry considering the way we treat those whom we playfully term militant suffragettes. And this suggests the strongest argument why they should have a vote. The chief function of our collective action is the spending of money on what we deem collective needs. Then, as far as possible, our collective action should be backed up by an overwhelming body of responsible public opinion. The more there are directly or indirectly associated with such action, the more stable is society. As we pass from barbarism to civilization, the enforcing of the law by mere public opinion should become ever more certain. How can this be secured if one great section of the nation rightly feel themselves aggrieved? No doubt, at present, there is sufficient public opinion to make it overwhelmingly powerful, as it is; but this should only make us the more sympathetic with those who go to certain doom in contending against its irresistible power. They resist the law, but it is the resistance of the martyr, not of the criminal. A political offender is one who breaks the law not to further any private interest, but to promote, as he rightly or wrongly thinks, a public good. To treat women, noble women, women of whom we should be proud, as common criminals, because they fight for rights in what they think is the only hopeful way of getting them, is unworthy of us as a nation. It is urged they resort to criminal practices. Well, where is the political offender who does not? If he does not break the law he is not an offender at all, not even a political offender. It is the fact that he breaks the law that constitutes lim an offender; but the motive with which he does it differentiates between him and the common criminal. So largely is this so, that history tells us of many an act which, as a mere crime, would have been visited with a small fine, but as a political offence has cost the unfortunate victim his head. If our militant suffragettes are a danger to the commonwealth, let us invent new and fearsome punishments to stamp out such pestilential offenders, but let us, at least, have some regard for our logic, and admit that political offenders they may be, but criminals they are not. 


\section{CHAP'TER III.}

COLLECTIVE OBLIGATIONS.

For what collective purposes are we entitled to demand contributions from one another? To demand money for wrong reasons or illegitimate purposes is to challenge our whole basis of society. No doubt the many, especially the organized many, are more powerful than the few, but that is only the more reason why we should act on principles, ascertained to be the best for all in the end.

To-day those things for which we collectively provide divide into three classes: (a) Matters of obligation; (b) Matters of quasi-obligation; and (c) Matters of no obligation.

As regards (a) there is little difference of opinion. Administration, law, order, and security must all be provided for, and paid for collectively.

As to (b), matter's of quasi-obligation involve more difficulty. In practice they mostly arise out of our relations with children. We agree that children have rights exactly the same as those of their elders, which ought no more to be invaded than those of anyone else, and we are inclined to see that they are not so invaded.

Now the highest right of a child is to be properly brought up by the persons responsible for its existence, and our obligation is really limited to 
seeing that such persons do their duty, and that it is so brought up. Unfortunately there are those whom nothing can compel to do their duty. Then our part in their case would seem to be clear. Having signally failed in their responsibilities to one child they should be effectually prevented from having another. Sucli rigour is demanded by the highest interests of the unborn, and of the race itself. And it would end the poverty and misery so rampant in our midst. We have no animus against the poor unfortunates, the chief offenders, themselves, often the victims of a vicious sentimentalism, and, so long only as they would not multiply their species, we would treat them with every possible consideration. As regards the poor little urchins we see thrown on our streets, the outcasts of God and man, it makes one's blood boil to think they were ever allowed to be brought into the world and nothing done to check the brutishness of their parents. And to relieve them, what does it mean? Only that their worthless parents will have yet other children to fill their place. 'I'hus we aggravate and perpetuate the evil.

Nor does it end there. If we merely keep them alive, what have they to thank us for; and if we bring them up respectably, we are using our collective resources to injure our respectable poor. No doubt it is well for the prosperous to be softhearted and sentimental; they do not feel the pinch, but it is entirely another matter for the lower industrial classes. They have to fight the aggravated competition, and they have to help to 
find the funds to bring up the very children who are going to fight them and theirs for their very bread. Talking pleasing platitudes is a pastime for the amateur philanthropist, but its results are fatal to the self-respecting manual labourer. However, this is a great subject, and here we will only refer to it so far as it involves the question of expense. We concede the right of liberty to all, including the right to have as many children as one pleases with this single proviso: If people voluntarily undertake responsibilities by having children they should discharge them. If instead they neglect to discharge them, if instead we have to discharge their duty for them, then we also have a very plain and certain right to make their neglect as unpleasant to them as we possibly can. The poor little children are crying to us to enforce this right. The injured respectable poor are crying to us to enforce this right, and our own very existence as a healthy nation is calling to us to enforce this right. And our not doing so is a grievous neglect of duty for which millions of those yet unborn will in a life to come of misery and shame have to pay the price. As a simple question-how can it be other than a curse to be the child of such parents $(a)$ ?

In one matter we are practically all agreed: a

(a) A drunken mother was with child. The doctor said when it was born it would be scrofulous, diseased or mentally defective. Events proved he was right; in fact proved that he could never have been other than right. To take the child, to nurse the mother, or even to prosecute the father is dealing with the evil at an entirely wrong stage. There ought never to have been such child at all. 
child must be educated. In securing the rights of the child we concede that to the same extent our own rights as parents must be curtailed. If we have a child, we are agreed that we ought to have it properly educated, and that it is right and proper for our fellows to see that we do our duty properly, and if another has a child we are equally agreed that we have a similar obligation to supervise him; but provided we respectively do our duty, none of us have a right to interfere with one another in any further manner. But, unhappily, experience has taught us that many parents so wholly neglect this duty that in the result we have to more or less discharge it for them. Whilst theoretically we should act thrcugh the parent, and only act independently when all measures have failed to make him do his duty, yet practically we have been compelled to establish a more or less complete compulsory scheme of national education. But whilst we would thus ensure every' child being educated, we must not forget the undoubted right of a good parent not to be interfered with in the bringing up of his child when he does so properly. The advantage to the child in being so brought up outweighs all other considerations. To it even the advantage of a uniform system of education should give way, and, so far as good parents do not unreasonably encroach upon the wishes or the purses of their fellows, they should be enabled as far as possible to indulge in their own peculiar idiosyncrasies. Liberty is a poor thing if denied us in the thing dearest to us-the upbringing of our own children. 
Thus, whilst general schools are necessary, and have to be maintained by money raised from us collectively, yet that is no reason why the utmost regard possible should not be paid to the wishes of the parents. The money paid by them to the public purse is as much money paid by them as money paid into the coffers of any particular school, and they should have as much voice in the disposition of the one as of the other. Where a number of parents have the same views this is easily secured, and to a large extent it would be possible to have a sufficient variety of scheols to suit a large number of parents who do not think alike. It is, indeed, pressing the doctrine of liberty far when it is urged that because there cannot be as many schools as there are parents therefore there must be one class of school for all. Because one unhappy man-a Buddhist say-cannot have his special curriculum, it is to be denied to others who number their millions. Still, provided their children were properly taught, we would even so far meet the smallest sets of parents that we would give them to the cost of their educational system the average amount contributed throughout the country. Education $(b)$ in the name of the child itself we insist

(b) The theory seems simple and clear. In practice another difficulty arises. If schools are to be of many varieties, it is only just that the teaching and patronage generally should be in proportion to the amount contributed to the cost of education. If certain schools are to be kept close preserves for any special set of teachers, there is serious danger that the same class of people will secure the lion's share of the teaching in the other schools as well. 
upon, but subject to this we also wish to be interfered with by our fellows as little as possible.

Our next division (c) is matters of no obligation for which we collectively provide. As to these, the serious questions arise when we have to deal with our unemployed and those generally who have failed in the battle of life. I here mention then for completeness only. The subject is a very large one, and I have dealt with it at length in another volume $(c)$. Here I will merely indicate one or two of the conclusions there arrived at.

In the first place, there is such a large amount of benevolence in the country that, provided help can be given in a wise way, there is no desire to limit it. If poverty, folly, and sin could be ended by a sacrifice of one half of our incomes, I believe it would be made. But any such quixoticism we know would not lessen but add to the sum of human misery. The vast schemes of relief mostly proposed at other's' expense would, I believe, be carried with enthusiasm were there any prospect of their doing any real good $(d)$. What troubles all is not what is to be done, but how it is to be done. Not what? but how? It is not a question of warmth of feeling or fulness of heart, but how an evil is to be grappled with and dealt with. Kindliness is the prerogative of 10 class, and certainly of no political faction. In

(c) Lilierty and Progress, Part III., p. 226.

(d) Schemes of charity at our own expense we can inaugurate at once; it is only when we want to be charitable with other people's money, and extra virtuous with other people's property, that discussion and delay hinder our mighty works. 
fact the only confident remedies proposed are by those who ignore or are ignorant of the teaching of experience. The more one considers the subject practically, theoretically, and historically, the more serious do the difficulties prove to be, so easy is it to do hurt in one direction whilst trying to do good in another $(e)$. But, remembering what we have premised as to benevolence, it would seem that the best results are to be obtained by running the principles of Individualism to their pitiless and logical conclusions. And the reason for this is obvious. To invade such principles in one direction is to cause a certain reaction in another.

Thus, take the case of our unemployed. Our basis of society is payment for services rendered. Then a man who can give his fellows no return has no claim upon them at all. Whatever he asks he must ask of charity and not of right. Nor has he the more right to another's substance, that he offers to give work that they do not want. And why is this distinction essential? Simply in the interests of others who are in work. Any money found to provide him work-work that is not wanted-is diverted from other people whose work is wanted. Every pound of capital that is bringing in interest is used in finding employment. So every penny of income

(c) An example of this is the way in which anyone handicapped by bad sight, injury, age, or other deficiency is hit by the Workmen's Compensation Act. He cannot contract out of the Act, premiums to insure him are prohibitive, and he cannot get any employment at all. 
spent equally is used in finding employment. There. fore, even to take a hundred pounds from the richest man to pay the unemployed leaves him with a hundred pounds less to pay for work in the ordinary channels of business $(f)$. Thus we cannot concede the right to work, or rather the right to be paid for unwanted work, without injuring other workers better entitled to be employed. Still more disastrous is it to the everyday worker if the help to the unemployed takes the form of doles which enable him to do ordinary work at less than market prices. 'Then another turn of the screw is given to our unfortunate sweated labourers, who find the competition for their job still further increased. One thing seems clear. As far as we help our unemployed, it must be entirely outside the pale of individualistic society. 'This does not mean that there is the slightest necessity that our poor and unfortunate should be dealt harshly with; on the contrary, they could be treated very well, and made reasonably happy; but what is essential is that they should be helped outside the limits of everyday life. Nor is the difficulty great. Their very numbers and the amount now annually spent point to the fact that what is most desirable is a simple consolidation of

$\left(f^{\prime}\right)$ This is well illustrated by actual instances. Under the old poor law, farmers were compelled to employ paupers. The result was they had actually to dismiss men to find them places. The result now is more indirect but not dissimilar. Even a duke, who has to find $£ 100$ extra for the unemployed, will have $£ 100$ less to spend in other directions, and it is quite conceivable if a gardener died or left him, he would leave the place unfilled. 
our poor laws and of our charitable institutions generally. As those needing assistance are the flotsam and jetsam of every class, this would enable us to have our homes or colonies for helping them on a scale sufficiently large for each to be a more or less perfect cosmogony of society itself. Thus we could find everyone the employment he was most fitted for, and whilst adding to his happiness by finding him congenial work we could fit him for a return to ordinary life when there was a demand for his services in the ordinary channels. But the precautions to be taken against allowing his work to affect the ordinary labour market, with numberless other details, would for their discussion demand more space than the nature of this essay permits of. We have thus mentioned the matter that we may here reinforce what we have said, that no one is entitled to demand of his fellows of right any relief. To their compassion alone is he entitled to appeal. Nor will such appeal be in vain. Remembering this, we see that the relief of our poor ought never to be made a matter of party. In strict justice nothing but the unanimous consent of all who have to subscribe justifies any levy being made for such purpose. What is wanted is that the wisest and best of every party should meet in consultation to discuss how most good can be done. Then the necessary money would never be wanting. But to make party capital out of such matters simply means the best things being always done in the worst way possible. When one considers the case 
of the poor it makes one deplore that the party system should prevail at all. Think what a magnificent body of accumulated practical and theoretical wisdom we should have in our Houses of Parliament if one common end animated all-to find what was best and do it. Such a consultative body the world would never have known before. What commercial company could prosper if there were always directors in two parties and their arguments were directed not to the furtherance of business, but to the "dishing" of the other side? However, one merit of our Constitution is that it readily adapts itself to every change of condition, and usually proves workable in the end. Every generation has its own peculiar wants and dangers to meet and face. One age sees a king too autocratic; another, and the lords are too domineering. Neither mischance seems a serious menace to ourselves. Our monarch finds his sure power in our affection and esteem, and his lords, in fear of their existence, are on their best behaviour. If any danger threatens, it is that temporary majorities in the Commons may try to ride roughshod over the rights of their dissentient fellows. But this carries its own cure, for whilst gratitude is a lively sense of favours to come, injuries suffered are never forgotten nor forgiven. Bribe never so cleverly, and you may have but a lukewarm friend for your pains; but make an enemy and he is an enemy for life. An even more serious risk is the temptation to bribe the electorate with pledges to be redeemed by other people. Thus in dealing with our poor we should, 
above all, be scrupulously just. Unless we all pay our due share we shall certainly end in an extravagance which will cause more distress than it cures. So we want to avoid the infallible nostrums of infallible cranks and adhere to a uniform policy approved by the average common-sense of our practical citizens. Especially do we want to avoid crude ideas suddenly flung upon the statute books. If a second chamber were of no other service than to compel some legislation to be reconsidered it would be invaluable; and we should measure its utility not by the good it has promoted but by the blunders it has prevented. Whether our House of Lords is all we can imagine is a matter of opinion. Personally, as one of the people, I would have my small say as to everyone who has power to bind me by legislative act. But it is clear that what we above all want in a second chamber is that its members should be above the wild gusts of passing feeling. As suggestions are rife, I may say that what might conmend itself would be a chamber of 400 members, with one-twentieth of them retiring and elected every year. This would give 20 years' service to each member elected, which should be enough to secure his personal independence; and at the same time the annual elections would keep the chamber as a whole in touch with public opinion. If desired, it could be modified by the inclusion of another 50 or 100 members selected from our great public servants, imperial or otherwise, to whom seats could be given during the term of their office or for life. As to those of our present 
lords who desire to devote themselves to public life, their influence is so great that they could as easily command a seat for themselves as they now do for their sons in the Commons. We, English, dearly love a lord-and not a few deserve it. However, this is going beyond an essay on taxation, though at the same time it is very material that all new proposals for raising revenue should be adequately and completely discussed and approved before becoming law.

\section{Note.}

We have thus considered matters which are rightly made the subject of general contribution. But crude attempts are also made to use taxation as a means of remedying certain wrongs more or less incident to our system of Individualism. With the exception we deal with later on this is neither sound in theory nor satisfactory in practice. We are agreed, for example, that Individualism is payment for services rendered. We are agreed that many are overpaid and many are underpaid-the why and the wherefore is the matter of a distinct inquiry-but here we must point out, taxation affords no remedy for such evils. If a man is paid too much, that is a reason for paying him less; and if he is paid too little, that is the reason for trying to secure him more. It is no satisfaction to the man who is paid too little that the man who gets too much is specially taxed not to benefit him. but to save the pockets of other people. If, to some extent, he is himself relieved, the benefit he so receives is but trifling compared to what he would secure by being justly paid. What is to his interest is that justice should be done generally. Still less is taxation a feasible system for remedying wrongs occasioned by actual unjust acquisition. The remedy for unjust acquisition is to prevent it in its entirety, not to wink at the evil to share the gain. Either prevention in its entirety or a police-court inquiry is the only reasonable alternative.

To tax is to penalise the many just for the sins of the knavish few. If I have paid every penny for a ship I 
possess, am I to be mulcted because pirates have stolen theirs? Surely leave me alone and hang them is my modest claim. But if property has been acquired under a defective law-well, change the law by all means; but "the original sins of acquisition have been blotted out by contracts of sale, and even Carl Marx admits the validity of this method of purification " $(g)$. In the economic as in the political world. as soon as any great disturbance occurs, the process of readjustment begins. The principle of prescription rests upon recognition of this fact, and, as Burke says, "If prescription be once shaken no species of property is secure" $(h)$. The wholesome rule is that, what is done under the flag the flag should support, and if the custom or law lends itself to unfair results, change such custom or law. The most that can be demanded from any is that he act in accordance with existing law. Having so acted, it is as much our duty to support him acting collectively as it would be if he made a bargain with us individually. "He that sweareth to his hurt and changeth not" as much applies to us acting together as acting independently.

(.) Nicholson, Vol. III., 1. 231.

(h) Nicholson, Vol. II., p. 157. 


\section{CHAPTER IV.}

THE BASIS OF TAXATION:

Is our first chapter we have indicated rather than traced the evolution of liberty and its connection with modern conditions. We have shown how Individualism is but the logical development of liberty carried to its possible limits. But just as liberty is the end, the very being of Individualism, so is just payment for services rendered its essential condition. And "services rendered" divide into two great classes-those we render and receive as individuals, and those we render and receive from one another acting collectively. Payment for both ought to be equally just. Here it is with the latter-payment for services we receive from one another acting collectively, otherwise taxation-that we are more particularly concerned.

And here let us be careful to get a clear conception of what we mean by State or collective action or responsibility. Some would write or speak of the State or community as if it had a distinct entity in itself. "The State should do this, the State should do that." Not so at all. As far as I am concerned, the State is only the rest of $\mathrm{my}$ fellow citizens. If I have made them a promise I ought to keep it; if they have given me their 
word they ought to be equally faithful $(a)$. In every transaction of life the question is, Do I owe anything to another individual or does another individual owe anything to me? If so, let there be a just settlement between us, and justice in no way will be varied by that individual being multiplied by seven, a thousand, a million, or even by forty millions. Pressed to its limits, it will be urged that this doctrine precludes any claim on another's purse apart from contract express or implied. And this conclusion seems sound. Some with a mighty charity with other people's goods are full of other claims, and glibly talk of what others can afford. But what a man can afford, whether for his own or other people's benevolences, is a matter solely between him and his own conscience, and is no business of anyone else whatever. If such a one pay his due, none has a right to even advise him how he shall use his own. No doubt, as Lord Beaconsfield well put it, "The tenure of property is the fulfilment of duty," and it is a duty grandly discharged by some of our noblest and humblest alike, but it is a duty on which we, as outsiders, have no right to offer an opinion. We neither know nor can know what a man's position is, still less say what he can or cannot afford. And it is this fact that makes what a man can afford unsatisfactory, or even impossible,

(a) "The legislator owes the greatest respect to this expectation which he has himself produced. When he does not contradict it, he does what is essential to the happiness of society ; when he disturbs it, he always produces a proportionate sum of evil."-Benthem. 
as a basis of taxation. Where alone it has worked fairly has been where the revenue has been raised by voluntary contribution. History tells us of some such communities, where each has contributed voluntarily and secretly his self-assessed share of taxation (b), and yet the public services have not suffered. But apart from such examples, the question what a man can afford is beside the mark. To satisfactorily determine it would involve a difficult question of fact in every particular case. Should bachelors be taxed? is a favourite topic with juvenile debaters, and yet all-important is the actual case to be considered. Are we to specially tax the man who denies himself the joys of married life that he may support a widowed mother, or help an unmarried sister or other needy dependant? There are not even any rough and ready rules to be applied, and to be only approximately just every case would have to be determined on its own merits. Between the varying units forming one community the only just principle is that of Individualism : as we receive, so let us contribute.

To some extent this is on the lines of the first of Adam Smith's famous four rules:- "The subjects of every State ought to contribute towards the support of the government as nearly as possible in proportion to their respective abilities; i.e., in proportion to the revenue which they respectively enjoy under the protection of the State. The expense of government to the individuals of a great nation is

(b) The Papal revenues are mostly of this description. 
like the expense of management to the joint tenants of a great estate who are all obliged to contribute in proportion to their respective interests in the estate" $(c)$. No doubt a higher ideal standard has much to commend it. Some would have it that a man should be trustee of his powers for the benefit of his country, and that from him to whom much has been given, much should be required.

The "faculty" basis, as it is termed, has met with the approval of some of our greatest economists $(d)$, and apart from theoretical considerations has much to commend it. Progressive taxation (e) approximates to such theory because most men's energies are devoted to making money, and the money made is not an unfair index of "faculty."

In this respect then we shall find it very closely approximate to the canon of taxation we have laid down, and we will now proceed to the consideration of collective contribution on the basis of payment for services received.

(c) The Wealth of Nations, Bk. V. Ch. 2, Pt. II.

(d) Nicholson, Pol. Econ., Vol. III., 27\%.

(e) Progressive or graduated taxation is defined and dealt with later on. 


\section{CHAPTER V.}

" SERVICES RECEIVED"-THEIR APPRAISEMENT.

We have thus stated on what basis we think collective contribution should be required, and in our third chapter we have briefly indicated the nature of the obligation for which it would seem it can be justly required. Then, taking it that we ought to pay our share on the basis of payment for " services received," let us now enquire how such services should be fairly appraised.

The most important service we one and all equally receive is security of life and limb. Let the meanest of us be injured in this respect, and he can rely on the combined action of us all to avenge him or secure him reparation. For this service a contribution in the nature of a poll tax may well be demanded. To every man alike his life and security is of supreme importance $(a)$. Possibly in this matter

(a) "To equal justice appertaineth also the equal imposition of taxes; the equality whereof dependeth not on the equality of riches, but on the equality of the debt that every man oweth to the commonwealth for his defence. It is not enough for a man to labour for the maintenance of his life, but also to fight, if need be, for the securing of his labour. . . . The equality of imposition consisteth rather in the equality of that which is consumed than of the riches of the persons that consume them."-Hoblyes" Leviathan; Morley's Universai Librar'y, p. 157 . 
the humbler members of society owe more to their fellows than the richer and stronger. The strong man, whether strong physically or mentally, can always be relied upon to take good care of himself. It is the weak and the poor and the helpless who are most dependent on the good offices of their brother citizens. But no considerable amount of contribution can practically or theoretically be expected to be received from this source. Practically it is out of the question. Those who most benefit, our poorest and most helpless, from their very nature are not in a position to contribute largely. Nor are we quite inclined to agree with John Stuart Mill, that even a theoretical case is made for the whole of our taxation being so raised if it only were practicable. Personal security no doubt demands first consideration, and undoubtedly something is due from each and all under this head; but it is by no means the only benefit we receive from one another, and certainly in $£ \mathrm{~s}$. d. not the most expensive. In paying for services rendered, it would hardly seem we should limit the idea of such services to securing personal safety alone. By mutual working together we manage to secure a total income not far short of the fabulous amount of $£ 2,000,000,000$ a year. Surely those who take the most, most profit by the co-operation of their fellows, and probably benefit at a progressive rate. We have referred to the enormously complicated conditions necessary to enable a vast population like ours to even exist in the limited area available. This has resulted in a corresponding growth of necessary collective expenditure. In 
addition to securing our personal safety and our property amongst ourselves, we have to make even greater provision for safety from foreign aggression. In this respect the man with great possessions, like the man who has to earn his daily bread, has not only his life and liberty at stake, but has also involved the security of his property. Thus he may reasonably be expected to contribute more to the maintenance of things as they are. So the more a man can earn by his labour the more he is concerned that there shall be no change for the worse, and he also should contribute in proportion to the benefit he so receives. It may not be possible to put one's finger on any one service and say, pay for that; but results as a whole should be paid for, and how to measure such results is the end of this enquiry. To charge for individual transactions in no way commends itself, and in fact the system of collection for innumerable petty services at every turn is usually very irksome, annoying, expensive, and unproductive.

These and the like considerations point to the conclusion that whilst a poll tax is to be justly demanded from all, neither in practice nor theory should it be the only measure of contribution.

Leaving then the amount that should be levied by way of poll tax to be determined as a question of fact by statesmen and practical politicians, we will now enquire a little further into the principles governing the further contributions on the basis of financial benefits received.

To-day we have two radically different classes of 
the community who benefit pecuniarily by the collective action of their fellows :-

(A) Those who do work for their fellows and are paid for it.

(B) Those who live on their income, as it is termed; or to be more precise, those who derive an income from property, of which the one characteristic is that it enables its owners to demand and receive from others the products of their current labour without giving them any products of their own current labour in return. To him who has to so give his labour, or the products of his labour, other incidents of property are not very material, and apart from security are hardly much more material to the owner himself. Whether his income is a charge on all the property of the nation, like consols or government annuities, or whether it is received viâ stocks, land, loans or any other form of investment is of little moment to the fortunate possessor. The income is the thing; it is the income that differentiates between his position and that of the man who has nothing but what he earns by his own work.

The incidents affecting these two great classes, as regards each of them independently as well as in their relations to one another, will be best dealt with in distinct chapters. 


\section{CHAPTER VI.}

CONTRIBUTION BY EARNED INCOME.

WIThout unduly hampering ourselves with definitions, often forgotten by the writer and usually ignored by the reader, we may speak of the incomes of those who do work and are paid for it as earned incomes, and of the incomes of those who receive them from property as unearned incomes. These terms have the merit of being concise, and as they conform to the popular meaning they are not likely to prove misleading.

The chief fact is, as we have already noticed, that between the two there is a fundamental difference, and such a difference as may well warrant a differentiation in the rate of contribution to be expected from them. This difference we shall preferably discuss after considering the different equities involved in each class separately and independently of one another. And first as regards earned incomes. These show the vastest differences. Some represent work done paid for by millions of pounds; others work done and paid for by farthings. How should the recipients of such incomes, as among themselves, contribute to the collective funds? Some economists of our older school contend that the amount should be simply proportional, 
that is, that each should contribute the same percentage irrespective of the amount of his income. The foundation of such reasoning is that the benefit received is proportional to the amount received. But is this so? In this view of the case, are not certain material factors being overlooked? This is rather the opinion of more modern economists who incline to think there is a case for graduated or progressive contribution; by graduated or progressive contribution meaning that the rate of payment as well as the amount should increase as the income itself increases. To what extent such rate should increase with increasing incomes is a question of fact which can only be determined after a lengthy enquiry. And it would seem there are several sound reasons in favour of such progressive contribution. In the first place, is it not arguable that a man increasingly benefits by a form of society which enables him to earn an increasingly larger income? Thus, may not a writer who in one form of society would receive nothing but a flogging for his wares owe much for the maintenance of another in which he is secured large fees for his efforts? So may not a singer who by some formalists would be chased out of a town be vastly indebted to others who seem hardly able to pay him too much? Then a lawyer politician, skilled in making the worse appear the better cause, may he not be progressively interested in maintaining a society where nothing is so well paid as good reasons for bad actions? And does not a trader receive services of progressive value from the main- 
tenance of a status quo which enables him to crush out competitors and secure millions for the payment of his own labour? And, generally, where, owing to favourable conditions, some are enabled to sell their labour at a far higher rate than otherwise they could do, do they not progressively benefit, and therefore should they not progressively contribute? Not the least important factor in establishing such favourable conditions is the possession of capital. Capital, as we more than once shall have occasion to notice, has two functions. One, to be let out on hire, of which we shall treat in our chapter on "Property in general," the other to enable its owner or handler to sell his labour at a far higher rate than he otherwise could do. And it is noteworthy that the greater the control of capital, the progressively greater the earnings or wages it secures its manipulator. The man with $£ 1,000$ is in a far superior position for selling his labour to that of the man who has none. So the man with $£ 10,000$ is in a different category from him who has $£ 100,000$, and both are overshadowed by the millionaire class who can sell their labour for fabulous amounts, and the multi-millionaire who simply absorbs the wealth of continents before he thinks himself adequately paid (a). So probably no business or economic fact is more generally accepted than that the larger a man's profits grow the less proportionate demand they make upon his

(a) For a fuller discussion of this function of capital, of enabling its owner or handler to sell his work at increasingly greater rates, see Liberty and Progress, p. 50. 
industry and exertion. Not one successful man but will tell you his first $£ 100$ took the most making, and every successive hundred was made with progressively less trouble. Many causes contribute to this result. In agriculture a well-known law is that of the margin of cultivation. In commerce a corresponding law might well be found in the margin of profit. The lowest profit that enables any trader to exist fixes the price. The more favoured trader, whether by the largeness of his transactions, the superiority of his organization, the economy of his working, or the cheapness of his finance, makes additional savings at every turn which all go to swell his annual surplus without in any way adding to his labour $(b)$. So far as this is so, it means that he is progressively indebted to a form of society which enables him to earn more with a steadily diminishing expenditure of energy. Some such form of progressive taxation has been recognized in most epochs of the world's history. For example, it prevailed at Athens where there were four Solonian classes of citizens arranged according to their wealth. Of these, the first paid no taxes. The classes above them were entered on the tax books at a sum equal to five times their income, the next class at ten times their income, the richest class at twelve times their income $(c)(d)$.

(b) "The rich man may be said to be sukject in some sense to the law of increasing returns. Money makes money." Nicholson, Prin. Pol. Ec., Vol. III., $27 \%$.

(c) Walker, Pol. Ec., p. 498.

(d) "So in England, graduated poll taxes were imposed 
The argument usually advanced against such progressive contribution is that it will kill industry. But it is clear that such progressive taxation would not check industry unless very excessive, owing to this very progressive facility with which larger sums are earned. A successful practitioner getting fees running into thousands of pounds, still more a patentee, and most of all a business man who is making his money with the aid of clerks, is not going to be retired by a tax of even ten per cent. on his earnings. And after all, such questions as checking industry or not, in principle have little bearing on the question. As a competitor I may well and rightly wish an industry checked which relegates me to penury and hardship. Certainly I am right in demanding that a favoured rival shall not for any fanciful reason escape paying his fair share to the necessary expenses of the State. So it is urged that we should not specially charge people who are doing valuable work. Certainly not; it is very undesirable to unfairly charge anyone. We want fair payment for services both given and received. That the recipients of large earned incomes get well paid for their services is evidenced by the size of their income. All that is desirable is that on the other side they shall fairly pay for the services they receive. It would almost be obvious as regards the man who receives such a large amount

in 1379 according to ranks and professions, a duke paying ten marks and an attorney half a mark (6s. 8d.) - the rudimentary form of a tax according to faculty." - Nicholson, Priı. Pol. Ec., Vol. III., 260. 
of the $£ 2,000,000,000$, the total of the national income, that so far from Mill's view of a poll tax being an ideally fair tax, his benefits are not merely proportional but distinctly progressive $(e)$. Therefore on the whole it would seem that progressive contribution, being based on progressive benefits received, is well founded $(f)$.

Were reasons of convenience to be appealed to, a yet stronger case could be made, as it is clearly to the interests of us one and all that large fortunes should be the exception and not the rule. Where moderate fortunes prevail there is more opportunity for the moderate man to do well. As most of us at best are but moderate this is what we should prefer; and we should decidedly approve of those institutions which limited fortunes to the amount we could just manage to secure ourselves. But the quicksands into which such considerations lead us are deep enough to engulf society $(g)$, and to-day

(e) It must be admitted that a strong body of authority is against such progressive taxation, headed by J. S. Mill, and including MeCulloch, Levasseur, De Parieu, Gneist, and Hermann. On the other side there have been Rousseau, the elder Mirabeau, and more modern writers like J. B. Say and Joseph Garnier. On this see further Bastable's Public Finance, 304. On p. 110 he sums up the objections that progressive taxation tends to become arbitrary, leads to evasion, prevents accumulation, and is not as productive as might be expected.

$\left(f^{\prime}\right)$ It is not very unreasonable that the rich should contribute to the public expense, not only in proportion to their revenues, but something more than in proportion.Adam Smith, p. 379 of McCulloch.

$(g)$ "The question of progressive taxation is a nice one in theory; while in its practical application it is beset with the 
as practical men we must act on the principles of society as we find them and do our best to act justly. Therefore it would not be safe to advance any such argument, and it would be a departure from our fundamental principle of "payment for services received." The benefit of a pitiless working out of the principles of Individualism to their logical conclusion so transcends any benefit to be got by the most plausible departure from it that the temptation to use such arguments must be sternly and firmly laid on one side. The ultimate greatest benefit to the whole will be secured by asking in every case, not what is convenient or pleasing, but what is just according to the first principles on which we conceive individualistic society to be founded. If, then, the principle of progressive or graduated taxation is to be defended, it can only be that the man who is enabled to earn an increasing or progressively increasing income progressively benefits by the society which does so much for him. That he does. so benefit would seem to be an undoubted fact.

gravest difficulty, arising out of the instincts of spoliation, which are deeply rooted in the human breast-an inheritance from ages of universal warfare and robbery. The appetite for plundering the accumulated stock of wealth, once aroused, may become a formidable social and political evil."-Walker, Pol. Econ., p. 500 . 


\section{CHAPTER VII.}

CONTRIBUTION BY UNEARNED INCOMES, AND HEREON OF PROPERTY IN GENERAL.

Our next enquiry is what contribution should be made by owners of unearned incomes, that is, by those who, without giving any current labour of their own, are in a position to demand and receive the current labour, or the products of it, from other people, in other words, are owners of property. As we have seen, the form of the property is not material. The income is what is material, and is equally material to the recipient and provider of it.

Here we are faced with the very practical enquiry, why should the rest of us worry over securing to any particular individual what is termed his property? Why should we enter into a self-denying ordinance to stand out of certain good things of this world, that one particular person may have the sole enjoyment of them? Still further, why should we actively interfere between him and another who would have a share? Apart from our support, his claim to exclusive possession would not be worth an hour's purchase. What is the reason for this extraordinary self-repression and generous intervention? Apart from collective co-operation, property ceases 
to exist. As Bentham well remarks, "There is no such thing as natural property at all ; it is entirely the work of the law" (a), that is, of mutual compact. And why have we made this mutual compact?-a compact which gives as much sanction to one form of property as to another, and to which for such sanction every class of property must equally appeal. Being an individualistic society, I do not think we need seek very far as to why we have made this compact-simply that we generally benefit by its existence.

As far as the owners of property are concerned, it would not seem that their case needs much demonstration. They have property, and we can imagine them uniting in a solid phalanx in its defence. So numerous are they-probably two-

(a) Bentham's Theor!y of Legislution, p. 111. So after inquiring into the basis of a law of property, he further asks: "Has not man in a primitive state a nutu'al expectation of enjoying certain things - an expectation drawn from sources anterior to law? The catalogue of these cases is very limited. The savage who has killed a deer may hope to keep it for himself so long as his cave is undiscovered, so long as he watches to defend it, and is stronger than his rivals. How miserable and how precarious is such a possession! If we suppose the least agreement among savages to respect the acquisitions of each other, we see the intr duction of a principle to which no name ean be given kut that of law. A feeble and momentary expectation may result from time to time from circumstances purely physical; but a strong and permanent expectation can result only from law. That which in the natural state was an almost invisible thread, in the social state becomes a cable. Property and law are born together and die together. Before laws were made, there was no property ; take away the law and property ceases."Ibirl. 
thirds of the nation, and those the strongest and wisest, that any direct attack on property is almost certain to fail $(b)$. But, happily, as regards the worker also he is almost as largely interested in there being property and abundance of it. In order that a worker may get the fullest return for his labour, it is essential that he should have the use of property ; and the next best thing to owning such property himself is that there should be others from whom he can hire it, and the more abundant it is the less will he have to pay for its use. A man who is able does far better in a country where property is abundant than where there is little or none. Thus, whilst the owner benefits, as he undoubtedly does, so also does the worker; and it is this fact that all benefit that establishes our institution of property on a sure and sound foundation. For what is property? - the products of work saved and not used $(c)$. 'This in itself would point to the worker not being injured by the existence of property. Two men work and receive the same wages. One saves sixpence a day, the other spends all he receives. Has either a grievance against the sther? No doubt when both are old men the difference in their position will be amazing. So little as sixpence a day accumulated during a man's working days-say from 14 to 70 - will amount to no less than $£ 2,600$. And apparently one has got as much out of his life as the other, and yet is $£ 2,600$ to

(b) See note at end of chapter.

(c) "Capital is the result of saving."-Fancett, p. 11. 
the good. A plain, simple working man. This enormous result of the accumulation of littles is hardly realized. No doubt some men do suddenly make vast fortunes, but far more fortunes are saved than made $(d)$. And when we realize what property is - that it is the accumulated result of many little acts of self-denial-we begin to understand why its owners feel so strongly as to their rights in it, and why there is such a general consensus of opinion as to the justice of such feelings. Our principle of Individualism is payment for services rendered. Surely this carries. with it the right to do what one pleases with the pay when received. So if instead of at once spending such payment one chooses to save it, shall not such savings be equally sacred? And if savings in one form wre exchanged for savings in another, is the nature of the rights in any way changed? And above all the man who will not save himself wants to encourage others to save for him. Savings are absolutely necessary to the effective carrying

(d) The author's father always insisted that a wife had more to do with an average man's ultimate prosperity than even the man himself. One would wonder why two friends equal in every way should end so differently. Perhaps each would start with $£ 1,000$ capital, and making about the same amount. But in one house all would be spent, in the other $£ 50$ a year would be saved. That $£ 50$ would be worth ten per cent. in the business, and it would mean that in about ten or eleven years it would amount to another $£ 1,000$ capital to work with. At the same rate of progression it would mean one would soon be well off, the other as he was. In money matters the plodding tortoise beats the impatient hare again and again. 
on of business. We have more than once referred to the fabulous total income of the country of nearly $£ 2,000,000,000$ a year. Apart from savings, or under conditions such as ruled 100 years ago; we could not make a quarter the amount. The man who saves is an invaluable asset to his fellows. $\mathrm{He}$ produces more than he consumes, and not only adds to the wealth of the country, but increases its potentialities for producing more. And see on every hand how we of the present have benefited by the savings of those of the past. In years gone by they were mostly invested in improving the land, and bringing it into the condition in which we now find it. But to-day there is wider scope for the investment of savings. Much is put into machinery to make labour ten-fold more productive; much into shipping to facilitate the exchange of products, to again largely increase the return for labour. So a large part of the savings of one portion of the nation las been invested in adding largely to the convenience of the whole, whilst an equally great amount has been used in rebuilding our cities and improving the condition of our people.

In fact, everywhere we have evidence of the savings of the past used for the advancement of the present. For in what does the wealth of the country really consist? Of course, its greatest wealth is its army of strong, virile, well-educated workers and thinkers, with next in importance the country itself, with its favoured position, its excellent soil, its splendid harbours and its other natural 
advantages. But apart from these, in what is it to be found? On every hand we see evidences of our wealth. Our roads $(e)$, our railways, our waterways and tramways, our bridges and canals are all invaluable assets ; our telegraphs and telephones, our wharves, our docks, our mighty navies and shipping, our vast factories and warehouses, our machine shops and equipments, our mines and our quarries are all vast items of our wealth. 'Then assets as vast we find in our drainage and our sewerage, our gas and our electric lighting systems, in our buildings and in our houses, in our palaces and mansions, and in our treasures of art, our treasures of antiquity, in our libraries and museums, and in the vast sums owed us by the other nations of the world. 'This is the wealth with which our ancestors have endowed us. How it is appropriated amongst individuals does not affect its reality. Were every deed, every writing, every ledger item of debit and credit erased, it would be none the less in existence--the gift to us from the past. 'The indebtedness handed down is but a matter of book-keeping; the assets real, tangible and concrete. Were our national debt, our municipal loans wiped out, the nation would be neither richer nor poorer. 'There would be a transfer of rights, but our assets would still be there. Whether they had a currency value or no would be immaterial; their intrinsic value to the community would be unchanged.

(e) Our roads alone Mr. Money estimates at about $£ 600,000,000$. Progress and F'orerty, p. 61. 
And what is the feature common to all these assets of wealth? All are the products of labour not consumed at the time, but saved. By these savings in the past we, of the present, benefit. If we had taken our country as the Saxon or ancient Briton had left it, we should have found it little better than a wilderness of forests, marshes and swamps. That it is otherwise is due to the savings and energy of our predecessors, who-instead of limiting their energies and consuming the whole of the products of their own labour and putting it into forms they could themselves enjoy-devoted much to permanently improving the country and ereating the wealth we have described, and we fortunate inheritors have entered into the fruit of their labour.

We see the resuits as a whole, we comment on them as a whole; and yet ever to be remembered is that these savings have been the many mickles that make a muckle, the savings of individuals who have been mainly animated by the desire to provide for their own wants and to leave their ehildren a little better off than themselves. Thus has wealth been created, and not the least reason that its ownership should be approved is that individuals, in thus saving for themselves and their families, have enormously benefited the community as well. Where would our country have been to-day if no rights in property had been recognised? Where would have been the industry, the accumulations, the progress of the past? What greater misfortune could have overwhelmed the race than to have 
denied them such rights in the products of their toil and self-denial?

And if our ancestors have not in all cases acted as wisely as we could have wished, yet let us remember the benefits we receive are real, hard, tangible, substantial realities, the encumbrances matters of bookkeeping. Some of their actions we hardly approve of and some of their dispositions of property we heartily condemn. But we must judge by the whole and not by isolated transactions. On these time has set its seal; we can neither remedy the wrongs of the past nor undo them, and in the attempt we shall cause far more suffering than we shall alleviate. Our danger ahead is the growth of an even greater disparity in the payment for current services. The evils connected with property tend to counteract themselves. 'The worker must have property to work satisfactorily, and at the same time the more property increases the less it can command for its hire. Even the vast accumulation of property loses its greatest evil when it passes out of the hands of the user to those who are content to let it out on hire. In the hands of the user, the worker, it may be a terrific engine to fight his fellow workers, rob the public, or crush employees, as witness many of the huge American trusts; but in the hands of the non-worker it is either lent for the lowest interest to the worker or is speedily dissipated by foolish habits. Thus on broad lines the institution of property is well justified by the benefit it confers on owner and worker alike. 


\section{Note.}

Those in possession would fortify their position with other sanction. Some rely on the law of property as part of the law of God. Unfortunately, those who dispute the one are not agreed on the other. So if property is held by divine command, it must be held on divine trusts and be used and only used as divinely directed. So the right derived from saving would seem a high one. If I eat my cake and you save yours, why should I claim a right to share it later on? If saving resulted in a curse to the many it might be reprehended, but as it is only a blessing, why is it to be penalized? And if you exchange your cake, or lend your cake, or hire out your cake, what possible business is it of mine, who have eaten my cake? And as society divides into those who have saved and those who have eaten their cake, a mutual protection league may well be formed of those who have saved, against the claims of those who have eaten it; a league in its last resource prepared to support its possession by appeal to arms. The argument that some in the past have stolen the cake they would now defend is bad as an excuse for an attack on all cake owners. The stealing should be prevented and punished, not honest owners attacked because some of their numbers are thieves $(. f)$.

(f) "Those who have the resolution to sacrifice the present to the future are the natural objects of envy to those who have sacrificed the future to the present. The children who have eaten their cake are the natural enemies of the children who have theirs." - Bentham's Works, Vol. III., p. 17.

"Economy has as many enemies as there are dissipators-men who wish to enjoy without giving themselves the trouble of producing. Labour is too painful for idleness; it is too slow for impatience. Fraud and injustice secretly conspire to appropriate its fruits. Insolence and audacity think to ravish them by open force."Bentham's Theory of Legislation, p. 110. 


\section{CHAPTER VIII.}

\section{THE SAME-continued.}

T'HE subject is so important that we may well pursue our enquiry a little further. How do actual figures bear out previous conclusions? Let us consider these as estimated by Mr. Chiozza Money. This necessitates our going back a few years, but in the life of a nation two or three decades even are not very material. Against this $\mathrm{Mr}$. Money is well known to have no undue bias for property or its rights.

Mr. Money estimated the total British income for the year 1904 at $£ 1,710,000,000$, of which he is of opinion that $£ 110,000,000$ was received from oversea profits and investments $(a)$. This leaves as the net home-earned British income, £1,600,000,000.

And how was this vast amount earned? With few exceptions employers, servants and capital are requisite for production under the most favourable conditions. The earnings of each are determined by well-ascertained laws, into which in another place we have fully enquired $(b)$. Here we are con-

(a) Riches and Pocerty, p. 14. "I take this figure here as it results in a round sum, and we are not really concerned with precise amounts, otherwise I should like to check it a little more closely."

(b) Lilberty and Progress, Part I., Chap. V. et seq. 
cerned with the proportions of this total respectively received by capital and labour. So it must be remembered we are enquiring not into the larger amounts for which the possession of capital enables some to sell their labour (these we know are sometimes fabulous), but into the amount that capital ean command for its actual hire. No doubt the employer in many cases is also owner of the capital, but what he receives for its hire, apart from what he makes by its use, must none the less be kept distinet. Where there are several partners in a firm this is always done. The hire for the capital introduced is always specifically agreed upon, and it is not an uncommon grievance of junior partners that old members of a firm will have in the business more than is required, and will also charge too much for it. What should be paid for such capital is well ascertained by what outsiders would be willing to lend it for. The charge so made will be quite independent of what return the user can get out of it. In fact, the more the user makes the greater will be his credit, and the less, therefore, will he have to pay for such hire.

And in estimating this hire it must be remembered that no inconsiderable portion of it is paid by way of premium for insurance against its loss. So much so is this, that not infrequently the repayment of money is actually insured by third parties, who charge so much per cent. for the service. So, also, a lender charges more if there are other troublesome conditions connected with his loan, such as 
his being unable to get its return without giving notice more or less lengthy. But when we consider what hire capital as capital commands, we have to take those conditions where a man knows he will get it back for certain, and with no undue delay or tormalities. To-day, in England, such capital invested on perfect security, like Consols, and practically at call, commands something under three per cent. interest. This rate, thus determined, has been termed by economists the natural rate of interest. Mr. Money has estimated for the year 1904 the amount of capital employed in business, $\& c .$, as comprised in what is known as schedule $\mathrm{D}$. of the Income Tax Returns, at $£ 3,34 j, 000,000(c)$. At three per cent. the annual charge on this would be $£ 100,350,000$. In other words, the cost of the hire of capital used in business operations would be just about a hundred millions. But this is not all that property must be debited with. To secure such income highly artificial conditions prevail, all intimately connected with property as an institution. The estimate of this further amount we get from the following table made up from income tax returns for this period :-

Schedule

A. Receipts from the ownership of lands, houses, mines, \&c. . $£ 251,700,000$

B. Profits from occupation of lands $17,500,000$

C. From overseas investments . $\quad \$ 4,900,000$

(c) Progress and Poverty, pp. 57, 58. 
D. Profits from business professions, employments, \&c. (including certain profits made abroad, say $£ 65,000,000)$. $£ 500,500,000$

E. Salaries of Government, corporation and public company officials

$$
\frac{86,000,000}{£ 900,600,000}
$$

Looking at this table, we see the two items with which property must be charged are the whole of the amount under Schedule $A$, and the $£ 100,350,000$, its proportion due under Schedule D. That is out of the total British home earned income of $£ 1,600,000,000$, property lent on hire receives as its share $£: 352,050,000$, leaving a balance of nearly $£ 1,250,000,000$ to be divided amongst the workers $(d)$. That the possession of capital enables some workers to secure far more than their share should not be laid at the door of capital lent on hire.

And to what extent does property contribute to the general productiveness of labour?

This we shall at once appreciate by glancing at the following table, which represents the energy developed in the United Kingdom at the periods stated. It is given by Mr. Mulhall in his review of the progress made during our late Queen's reign, and he takes as his unit one million of foot tons daily.

(d) These figures are rough calculations only, but are sufficiently accurate to illustrate our argument.

E 2 


\begin{tabular}{|c|c|c|c|c|c|c|}
\hline & Hand. & & Horse. & Steam. & Total. & $\begin{array}{l}\text { Daily cost } \\
\text { per unit. }\end{array}$ \\
\hline 1840 & 2,220 & 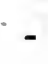 & 5,100 & - $\quad 2,400$ & 9,720 & $-\quad 28 \cdot 7 d$ \\
\hline 1870 & 2,700 & - & 5,600 & -15.750 & $-24,050$ & $15 \cdot 4 d$. \\
\hline 895 & $-\quad 3,200$ & - & 6,330 & - $51,880^{\circ}$ & - 61,410 & $8 \cdot 9 d$. \\
\hline
\end{tabular}

The most cursory examination of these figures shows how enormously labour has benefited in efficiency by the use of savings. The cost per unit has decreased from $28 \cdot 7 d$. to $8 \cdot 9 d$. in less than sixty years. That is, there is a reduction due to the use of savings of nearly $20 \mathrm{~d}$. per unit; that is, if property took the whole of this $20 d$. there would still be left for labour as much as partially-assisted labour earned in 1840. But property takes nothing like 20d. Out of the total of $£ 1,600,000,000$ its share of $19 s .8 d$. would be $£ 1,100,000,000$, whereas we have seen it only secures a trifle over £3j0,000,000. This conclusively shows that the hire of capital is not at all dependent on the yield it is instrumental in bringing about, but on its abundance and the competition of its owners to have it used ; then the greater its amount the less percentage it receives. If property took all the increase it was instrumental in bringing about, labour would receive only $£ 500,000,000$ instead of the $£ 1,250,000,000$ that falls to its share.

Mr. Money has also estimated how the total income is divided between those with more and those with less than $£ 160$ a year, or, roughly, with more or less than $£ 3$ a week. Those with more, including what they receive from oversea sources, he estimates at $£ 830,000,000$, those with less, at 
$£ 880,000,000$. 'Thus, thanks to 'savings, those earning $£: 3$ a week and under receive nearly double what the whole of labour would earn if it were no more assisted by property than it was in 1840. So, what is even as satisfactory, is that the same earners of $£: 3$ a week and under receive $£ 880,000,000$, as against the total national income in 1867 of $£ 814,000,000(e)$. That is, they receive $£ 66,000,000$ more than property owners, and worker's well paid, over paid, and ill paid, all received together. After making all allowances for the increase of population, these fiyures are simply stupendous, and as satisfactory as stupendous. Equally satisfactory are the figures Mr. Mulhall gives of comparative efficiency. Conclusively, they show how much of our prosperity as a nation is due to our superiority as producers, again due to the magnificent way our shops are equipped, again due to our savings as a nation, again due to the energy and self-denial of those who preferred to accumulate rather than dissipate their earnings in the past. The daily cost in pence per million of foot tons of energy is-Scotland, 6.9; England, $8 \cdot 7$; Ireland (alas!), $16 \cdot 1$, with an average for the United Kingdom of 8.9 ; France, 12.8; Germany, $9 \cdot 9$; Austria, $14 \cdot 4$; and Italy, $19(f)$.

The most cursory glance at these figures gives an insight into the true road to prosperity as simple as

(e) Progress and Poverty, 310.

(f) All these figures bristle with difficulties. But so far as they are comparative and arrived at in the same way they may help us in our inferences to conclusions that in theory are fairly sound. 
convincing. It is by welcoming and making safe the capital which so enormously adds to the efficiency of labour, and which yet, as we have seen, is content to leave to labour such a large proportion of the products produced. But we need not carry the subject further. With these figures it is not necessary to demonstrate the rights of property to some adequate share of products, to the increase of which it has so largely contributed. It is not a case of property depriving labour of anything, but of property making labour far more productive, and then taking for its portion a share of the surplus $(g)$.

(g) "But perhaps the laws of property are good for those who have property, and oppressive to those who have none. The laws in creating property have created riches only in relation to poverty. Poverty is not the work of the laws; it is the primitive condition of the human race. The poor man in civilised society obtains nothing except by painful labour: but in the natural state can he obtain anything except by the sweat of his brow? . . . The laws, in creating riches, are the benefactors of those who remain in the poverty of nature. . . . Tyrannical and sanguinary laws have been founded upon the right of property, but the right itself presents only ideas of pleasure, abundance and security. It is that right which has vanquished the natural aversion to labour, which has given to man the empire of the earth, which has brought to an end the migratory life of nations, which has produced the love of country and a regard for posterity. Men universally desire to enjoy speedily-to enjoy without labour. It is that desire which is terrible; since it arms all who have not against all who have. The law which restrains that desire is the noblest triumph of humanity over itself."-Bentham, Theory of Legislation, p. 114.

In fine passages he shows how, from want of security under the Turkish rule, some of the richest parts of the world have sunk into beggary, and then contrasts what security has done for the American colony when seen side by side with savage nature. 


\section{Note.}

Having regard to the enormous benefit thus conferred on the worker by capital lent on hire, it is somewhat difficult to understand the attitude of much Socialist thought on such questions. The Socialist programme is twofold. (a) Collective responsibility, moral and social, of each for all, and all for each. (b) Collective methods of wealth production. Some of their advance guard also advocate communism and other isms, but these are not an essential part of the socialistic theory.

As regards (a), many outside their numbers are prepared to share their sentiments to the fullest extent. As to (b), the reason for its existence is that, also in common with others of different schools, Socialists deplore the terrible inequality in the payment for services. This they believe can only be cured by collective co-operation in everything relating to production and distribution. To do this they would have collective control of all capital necessary for such purposes. But whatever the communistic section might wish, it is no part of the Socialist programme to divide up property, and they perfectly well realize the importance of capital to production. Whether capital is used collectively or by individuals it is equally an essential to progress. Thus the Socialist acting collectively still wants capital to be abundant just as much as the individualist Apart from communism the more abundant it is the less it will cost the collective users for its hire. And how is capital to become more abundant? Simply by saving. And how is saving to be encouraged? By making savings secure. So to be of service to the home-worker, whether as part of the collective machinery or not, the savings must be employed at home, but that they may be so employed, home employment must offer advantages that induce the savers to keep them in the country $(h)$. But seeing that the institution of property is as much part of a collectivist theory as that of the individualist, why so much misdirected agitation against it? There are great economists in the Socialist ranks; how is it that they suffer attacks which are as subversive of their ideals as of those of the individualist himself? And, further, it is these

(h) Not one of the least cogent reasons for land being regarded as property is that it thus affords scope to the saver to use his money at home rather than hoard it or send it abroad. 
attacks-which, if successful, would be as fatal to collective wealth production as to the methods now existing-which bring so much of the odium on the Socialist cause. With collective responsibility for each other's well-being many are in accord. With a desire to more equalise earnings as many more. Then why assume the incubus of war on property when success would be more fatal than failure? Personally, I believe with man's nature what it is, that with all its disadvantages individual production must always prove superior to sollective production; but at the same time I should like to see the fight fairly and squarely waged on the main issue, and without its being involved with communistic propaganda which are really no part of the Socialist theory. 


\section{CHAPTER IX.}

CON'TRIBU'TION BY UNEARNED INCOMES-CONDITIONS TO BE OBSERVED.

Nothing could be more satisfactory than that the benefit of property is general. This is its justification as an institution, this is the justification of Individualism itself.' And this fact is the reason why other schools have but a passing influence. In the end attacks on property always rebound with disastrous effect on the worker generally. As regards the employer the effect is obvious and instantaneous. If he owns property he suffers by the direct attack, and if he does not, we have seen that the next best thing for him is to be able to hire it from those who do and at the lowest rate. But attacks on property in any form immediately lessen the amount and increase the cost of its hire. Then the servant also feels the disastrous effect, though only indirectly. His employer, finding finance difficult, has to limit his operations. which directly lessens employment. Thus taught by sad experience of empty larder and hungry household, the respectable worker begins to dread - and rightly dread--any changes which may disturb his employer. No doubt there are many to-day who gravely fear that our country is gravitating 
to the condition of that of many an ancient civilization, where the population surely divide into a nabob class on the one hand, and a servile class on the other. Happily we have seen this is not the case. On the contrary, we see that the greater the abundance of capital the greater the competition amongst its owners to have it used, and the less. in consequence they will be able to demand for its hire. So in our own country we have seen how this theory has been borne out by facts, and we have noted how small a proportion of the total earnings capital is able to secure. Further, we have seen how the benefit of abundance of capital has been communicated to the less well-paid workers, and how enormously those receiving £? and under have increased their total earnings. The undoubted outstanding evil is the enormous disparity in the payment commanded by different classes of honourable workers $(a)$, but this is in no. way due to capital lent on hire. How far such inequality can be dealt with by taxation we have discussed in our consideration of earned incomes, and in our next chapter we will consider what further can be done when the accumulations of such saved earnings come to pass at the time of death; but here for the moment we are dealing with what contribution ought to be made by those actually for the time being in receipt of unearned income. In settling such amount there are one or two con-

(a) Dishonourable workers should not be taxed but prosecuted out of existence. 
siderations that should not be lost sight of, and looking at the question from the point of view of the worker himself, we see that what, above all, he wants is an abundance of capital available for his use. This suggests two broad rules the worker should observe when he would tax property :-

(a) Accumulation should not be checked.

(b) It should not be so harshly treated as to be driven abroad to find employment.

Then (c), there is the subsidiary principle to be considered, that all property should be treated impartially alike.

Probably there is less danger of checking accumulation than of driving its owner to seek investments in foreign lands. What the owner of property wants is simply the best interest he can get consistent with the amount of risk he is prepared to run. Other things being equal, he is not concerned in what country his savings are invested. But the worker is vitally concerned. The hire paid, we have seen, is but a small part of the increase that capital is instrumental in bringing about. Which worker is to benefit by the surplus is of the vastest importance to him. Hence it is that new countries are so clamorous for capital. Opportunities for its profitable use stare them at every turn. In old countries the amount is often more, and the opportunities for its employment not so obvious. Therefore there is a plethora of it, with a consequent fall in the hire it can command. But its owners have no difficulty in finding employment for it abroad. Their only difficulty is to properly measure the risk run; this done, 
a higher rate of hire for the same risk can be obtained in new countries than in old. The one great inducement that England can offer above other countries is the superlative excellence of her security. This wanting, the surplus savings $(a)$ which go to make business brisk, simply fly to other lands. Therefore every possible outlet for the safe employment of capital at home is the greatest boon to the worker. Thus, however much labour may desire to benefit at the expense of capital, however envious earned incomes may be of unearned incomes, yet self-interest cries with no uncertain note, "Hands off! Let unearned income pay what is just, but as for penal taxation, none of it." It is poor business to save a pound in taxation if it means driving capital out of the country which would have brought in five. If Mr. Money is correct-and he certainly is not far wrong-it would seem that $£ 3,340,000,000$ of capital are employed in bringing in a return of over $£ 500,000,000$ per annum (b), a return not far short of 15 per cent. That is what capital is worth throughout the country. (Of this the owner gets his :3 per cent., and the chain of users the balance(c).

(a) We want not only to use the savings of the past, but to increase them by the savings of the present.

(b) Probably part of income under Schedule E. should also be taken into the account.

$(c)$ It must not be forgotten that this will be the aggregate profit of many transactions. A man buys a coat from his tailor, who buys the eloth from a merchant, who in turn orders it from the manufacturer. The latter gets his wool through a broker, who buys from the importer, who pays the shipper, and at each and every stage workers or clerks are paid their 
Thus every ten millions unnecessarily frightened abroad is a dead loss to the worker of considerably over a million pounds a year in profits and wages. So further, capital sent abroad means the worker having to pay a higher rate of interest for what remains at home. How this cripples enterprise is easily seen. At one time for a payment of four pounds a year he may be able to hire as much as $£ 120$, whilst with less offered, $£ 100$ may be all he can get. So it is the competition of property owners amongst themselves that, in many cases, accounts for a steady rise in capital value. Where the annual payment is fixed, its value in the market will be governed by the amount of money available for similar investment. Not the least potent factor in the steady increment in the value in the past has been this accumulation of capital wanting employment. For a given annuity, capital owners have been willing to give a steadily increasing amount. Whilst those workers committed to definite payments may regret they did not secure the higher price for them, yet the workers for the time being benefit by the higher prices attained. On the other hand, when for any reason money for investment becomes less plentiful, the price to be paid for it steadily increases, with the result that industry is seriously checked. Thus it can be well understood that no director would feel it just to old shareholders to extend works by issuing new capital,

wages. In fact, the serious aspect of driving capital out of the country is this cumulative result. 
when for every pound he would have to pay in interest he would only get $£ 25$ instead of $£ 30$ as originally contributed. So much as to penal taxation being undesirable even from the worker's point of view.

Then from the worker's point of view it is equally desirable that in taxing property no unnecessary loss should be occasioned, and this brings us to (c) - the subsidiary principle that all property should be treated impartially alike. In the first place, to unfavourably treat any accepted form of investment is to make it taboo, to drive capital from it, and to flood other industries with an undue amount. This has the effect of disorganising them, subjecting them to undue competition, and making things generally uncomfortable. But, secondly, the effect on the property itself is extremely serious. The putting any new tax on any special form of property has the result not only of imposing an annual charge which may be trifling, but of causing a depreciation of capital value which can never be other than serious. The value of all income-yielding properties is determined by their values inter se, and a general uniform level of actual money yield or other equivalent advantages is maintained by all. To therefore tax one by itself is to reduce its capital value relatively to all the others, sometimes with serious consequences. If, for example, we supposed $\mathrm{Mr}$. Henry George's proposals as to Consols to be inaugurated with a trifling tax of $1 s$. in the pound on income received, what would be the result? Not a serious matter, one would say. But, query? The 
first effect would be an immediate fall of five per cent. in the capital value of Consols, i.e., stock worth 84 would fall below 80 . But it would not end here. Many holders of stock borrow on it, and as banks will lend with ten per cent. margin, it might well be that such depreciation would mean the destruction of half the borrower's interest of $£ 8$ in each $£ 100$ (nominal) worth of stock. This would be serious, but not the end of his loss. The banks would want their margin kept up, and as the time of a loss is the last time when a borrower can find further margin, the banks would have to realize. This would mean a further fall in value, and if the bank sold for 78 the borrower would have reason to be well satisfied with the price. But serious as such taxation would be in the case of Consols, it would be far more serious in other forms of property. In Consols a close price is always to be had; in other security markets the fall would be far more serious $(d)$. Nor is there reason for singling out any form of property for special taxation. All classes of property are indifferently dealt in. All, from an income point of view, have the same incidents. All rise or fall in value as there is more or

(d) Effect on capital value, discussed by Prof. Seligman, The Shifting and Incidence of Taxation, p. 182. He points out how the effect of a tax on any one article is to cause its depreciation in capital value, e.g., Railway Stocks which at 100 pay 5 per cent., if taxed 1 per cent. will fall to 80 . Thus he aptly sums up his enquiry: "With all these qualifications, the capitalization of taxation remains an important topic in the study of incidence. Its cause is inequality; its result is confiscation or gratuity." (p. 186). 
less capital for investment, all move equally sympathetically with the general prosperity of the country. The justification of all property is the justification of each special form of property, the worker benefits by its institution $(e)$.

But whilst we agree that there is no need for penal enforcements against income from property in any form or every form, yet on the other hand we are not prepared to follow those economists who estimate the benefit of accumulating capital so highly that they would be inclined to treat incomes from it even more farourably than incomes earned by work. For ourselves, whilst admitting how much the man without property benefits by property, yet still the fact remains that the person who has the property has all the advantages of the worker and others in addition. Our principle of Individualistic Society is that people should pay their just value for services received. Whether such services are received from one another separately or from the whole collectively, makes no fundamental difference in this respect, and the only question is, How should such services be assessed?

Probably the services received are directly proportionate to the amount of the income received, and the reasons for graduated taxation, as in the case of

(e) Not the least merit of Individualism, carried to its logical conclusion, is that the very recognition of the rights of property reduces its return-giving power to the very minimum figure. This in itself is an advantage not to be ignored by all who have to make their living by the labour they have to sell. 
earned incomes, are wanting. Whether Ireceive $£ 100$ a year or $£ 100,000$ from property, it would seem I should pay at the same rate, and as a mere income it seems difficult to find any reason for differentiating between the two. The services both receive are about proportionate to the income enjoyed.

Then, as between earned income and unearned income from property, what is the relationship that ought to be maintained? Before finally answering these queries, let us enquire into the nature of the charges that should be made on the transmission of property at the time of death. 


\section{CHAPTER X.}

TRANSMISSION OF PROPERTY AT DEATH.

We are agreed that the institution of property finds its justification in the fact that it makes labour more productive, and asks for its reward only a share of the surplus it has been instrumental in creating. Thus self-interest, the moving spring, should secure to a man extensive rights in his earnings and his savings when he is alive; and the question is what powers of disposition should he have over them when he is dead. Many reasons may be advanced why a man should have extensive rights in his lifetime which are wholly beside the mark when death has asserted its supreme power. With the hour of death rights end. A life interest is the utmost any can possess. A man may have wishes as to what he would like done with his property when he is no more, but why should his wishes be carried out? That a man may be entitled to his own savings is one thing, but that on his death another should take them, to the exclusion of everyone else, is purely conventional. The dead man may have willed it, but why should his will be considered? 'The dead render no services; they are objects of neither hope nor fear; then why should he be regarded? Simply for the same reason that his rights in his lifetime 
were regarded; because it benefits his fellows that within certain limitations his wishes should be considered. Making provision for one's widow and children, and the being able to nominate one's successors, are potent factors in promoting that saving so desirable for all $(a)$. So, further, what one does for another one hopes to have done for himself ; and as property owners in most countries are in a majority-often those with the least having the keenest sense of their right in it - the disposition to respect the will of the dead is very strong indeed. No doubt the prodigal are always very anxious to divide with the prudent, but in the end the "haves," not the "have nots," have usually proved the stronger.

But, looking at the subject philosophically, and remembering the benefit that the institution of property is to all, let us ask what can justly be charged against it on its transmission at death?

Certainly a reasonable charge is that for carrying out the wishes of the dead man. Apart from such assistance, it would be useless for him either to have any wishes or to express them. As to the fortunate recipient of his bounty he has only reason to rejoice that he can reap where he has not sown, and gather where he has not strawed. His attitude should be one of simple thankfulness that it is to

(a) "Were it not for the family affections, many who now work hard and save carefully would not exert themselves to do more than secure a comfortable annuity for their own lives."-Marshall, iv. c. vii. $\$ 6$. 
the interest of his fellows to support a system by which he so directly benefits.

Then in addition to such charges for services rendered, as Bentham points out, the period of death affords the desired opportunity of dealing with some of those inequalities of fortune which are the serious blot on Individualism. Our policy is to let a man have the utmost liberty possible in all his transactions when alive, and then on the passing of his property on his death to reconsider the situation (b). And here, be it observed, we are referring to property acquired by honourable methods-evil practices should not be permitted at all-and to cases in which we can do nothing but admire and applaud the builders of such magnificent fortunes. Thus we see some giants of industry who have never been party to even a doubtful transaction getting paid in millions, whilst others, equally industrious, cannot even secure a bare living. As no mark of disapprobation, but simply to prevent the accentuation of such disparity, it seems well that some attempt should be made to remedy what otherwise may become a serious evil.

Then what time can be better than when one

(b) "Is it necessary that between these two rivals, security and equality, there should be an opposition, an eternal war? With a little patience they may in a great measure be reconciled.

"The only mediator between these contrary interests is time. Do you wish to follow the counsels of equality without contravening those of security? Await the natural epoch which puts an end to hopes and fears, the epoch of death."-Bentham's Theory of Legislation, p. 122. 
man has just ceased to have an interest in his property and before another has entered into its enjoyment? Remembering, then, that the institution of property is mostly beneficial in the inverse ratio to the amount owned by each, we find very powerful reasons for making progressive charges for carrying out the wishes of the dead. A system of society which enables units to accumulate fortunes running into many millions, like that of an oil king, is sufficiently defective to cause the gravest concern; but a system which would perpetuate the existence of an oil-king clan for centuries can never be other than an evil of the greatest magnitude.

But, even here, self-interest demands that in dealing with such cases we should be reasonable and moderate. Of course, the first thing that should be done, if possible, would be to prevent such accumulations being made. No society, individualistic or anything else, can be healthy where such results are possible. It cannot be well that any man should be so fabulously paid for his work. By no stretch of the imagination is it possible to imagine a case where he has given in return services of anything like equal value. But here let us point out that to the body of workers at large such accumulations are not an unmixed evil. So far as they are due to charging consumers too much and paying assistants too little, so far they operate to effect compulsory self-denial and consequent saving. 'The parties concerned may get no benefit from their deprivation, yet labour generally benefits by the resulting increase of capital just as much as if it 
had been made by the unfortunate individuals themselves. It is in this sense that some old economists speak of it being possible to promote thrift and prosperity by taxation. Certainly this is so, and it is one of the reasons why the reduction of national debt has usually a beneficial effect on the business of a country. It collects small amounts from the many which would otherwise be largely dissipated, and which, repaid in larger surns to investors who want money used, serve in the aggregate to add somewhat considerably to the working capital of the nation.

And this brings us to the further reason why the taxation of all savings passing at death should be reasonable and moderate. Every penny so taken is taken out of capital actually employed in running the business of the country. To take out of everyday active commercial life large blocks of capital, i.e., money already saved and set aside for use, must always be more or less inadvisable. It is far better to take it out of income, which probably prevents its being wasted in extravagance or other unproductive employments, than to take it at a time when in fact it is being productively employed. It is true capital is saved income, but it does not follow that if capital be taken that income will always be saved to replace it. It is only as a matter of book-keeping that there is any difference between a nation living on its capital or living on its income, so long as the whole is not lessened; but is this whole never lessened? And what has to be remembered is, that the money levied at death does in 
fact deplete our store of national capital-capital actually employed in productive undertakings; whilst money taken annually as a rule means compulsory saving, and that the owner, instead of spending his income in one direction, has to spend it in another.

Coming back to our original question, we enquire, What should be the relative amount of contribution by earned and unearned incomes?

As regards earned incomes, we have seen there are the strongest reasons for graduated or progressive taxation, whilst as regards the income from property, we have seen that it ought to bear a charge proportional to its amount, and a further progressive charge on its transmission at death. But we have also seen that it is undesirable to make those charges too great at the actual time of death, and it would seem better to make an annual graduated levy, and so in part anticipate the charge to be made on its passing at death. And by so doing we are enabled to charge a uniform tax on all incomes, earned or unearned, and to graduate them all on the same scale. Whether unearned incomes should be charged rather more than earned incomes is somewhat difficult to settle. Putting refinements on one side, there is not a doubt that a man who receives $£ 00$ a year from investments is in a far superior position to the man who has only $£ 500$ from his daily labour. If the question were who could best afford to pay the most, there could not be a moment's hesitation as to the answer. But that is not the question. The question is, Services received, what should be paid 
for them? But here, again, it might well be said that surely a man owes more to a society which enables him to sit still and draw $£ .500$ a year without doing anything, especially if inherited, than the man who can only secure the same sum if he works his hardest the whole year round.

But against this the recipient of the unearned income may well urge two things. If the income is received from his own actual savings he may well ask why he should be doubly penalized. The man who has received and spent the whole of what he earned has neither benefited his fellows by his savings nor yet by paying any taxes on them ever will do so; and secondly, he may say if he has inherited his income that he has already paid for the benefit so received. No doubt the question is a difficult one, and so we are once more driven back to our general conclusion, that it is suicide for labour to penalize home investments. Doing so certainly drives owners to seek investments in foreign countries, where such burdens are not imposed. Directly a man feels he is being unjustly treated, he will do his utmost to get his rights, but treat him fairly and, as a rule, he will not make attempts to escape paying the same as others do. One example of evasion. Owners of foreign stock do not have dividends transmitted to England to have income tax deducted, but use such income to buy other stock with. This they can there sell at its market value. Perhaps, on the whole, there may be a case for charging unearned incomes a trifle more than earned incomes, but it is doubtful if it is a prudent way of raising revenue. 


\section{('HAPTER XI.}

AS TO PROPERTY IN CER'TAIN FORMS.

At this stage we may well enquire whether any differentiation should be made between incomes earned in particular trades and incomes received from particular forms of property. There is generally considerable talk about that most loosely used term "monopoly." Monopoly of capital, monopoly of land, monopoly of trade in intoxicants, monopoly of patents, and monopoly of trusts. Probably the most desirable monopoly of all is that of a nice large income, whether received from earned or unearned sources. Probably such monopoly virtually includes the others, and as long as we receive much and give little we are not much concerned as to the source of our good fortune. There are some who are anxious that luxuries in especial should be made to contribute largely to the general necessities, but, all said, there is no luxury like the luxury of a large income, and whether it is spent in meal or malt makes little difference in the fact that it is the supreme luxury of all. But we have fully discussed the principles on which such incomes should be taxed, and the question now is whether such incomes should be taxed a little extra when derived from special sources. Let us say a few words as to each. 
The first, and by far the most important, monopoly is that of capital, which enables its owners to sell their labour at much higher rates than they otherwise would be able to do. This function of capital, as distinct from that of capital let on hire, we have considered in our previous chapter, and have found in it one of our strongest reasons for having progressive taxation in the case of earned incomes. Here we need say no more on the subject.

(1) The next most talked of monopoly is probably that of land. So far, we have spoken of property as the products of labour saved and not consumed. An apparent exception is land, which does not owe its actual existence to labour. But even as regards land there is the vastest difference between what it is and what it was originally when it was little better than swamp, morass, forest and wild (a). The draining, the roads, the railways, and the development and improvement of land generally, which give it its value, are as much within the category of property as any other products of labour saved and not consumed. As regards rights in it they are simply no higher and no lower than rights in property in any other form. They owe their origin to the same mutual compact and their continuance to the same good faith (b). As regards

(i) "The rent that is paid for agricultural land is partly, and very often largely, simply interest on the various forms of capital sunk in and about the land."-Nicholson, Vol. III. 321.

(b) "If industry creates, it is the law which preserves; if at the first moment we owe all to labour, at the second 
all property, those without may well argue against the institution, though, as we have seen, even in their case, without reason : but as regards those who possess it they must stand or fall by it as a whole. The owner of one species of property cannot be false to his compact as regards property in other forms and hope to retain his own as sacred. Property in every form, in natural advantages as well as in the saved products of labour, has been so freely interchanged for hundreds and thousands of years that it is now impossible to disentangle or distinguish between different varieties without doing the gravest injustice $(c)$.

As a theory, some schools contend that land cannot be the subject of property. But why not? All property is the creation of the law; why must land be any exception? And granting the contention were well founded, still it would be very wrong for us in one generation to say, land is the subject of property, and so induce others to give other property in exchange for it, and then in the next to say it is not, and calmly resume possession of it by the mere right of numbers $(d)$. Whether we act collectively or individually, our word should be equally sacred. No

moment and every other we are indebted for everything to law."-Bentham's Theory of Legislation, p. 110.

(c) The admissions by Carl Marx, which we have before quoted, that the original sins of acquisitions have been blotted out by contracts of sale, particularly applies to dealings in land. See note to Chapter III.

(d) "Land nationalization without purchase is palpably unjust; land nationalization with purchase is as evidently inexpedient."-Bastable, Public Finance, p. 185. 
doubt such aphorisms as Land should be free as air, Land by natural law should belong to all, \&c., sound plausible and learned, but really carry the argument very little further. It is conceivable that in pastoral tribes individual property in land may be impossible, and in agricultural communities it may be modified, yet the tenure of land in every country nust be governed by conditions peculiar to that country. As regards ourselves, the fact stands out in the boldest relief that nothing but a most highly developed civilization makes it possible for over forty millions of people to live together in these small islands. Property in land is but a small part in a most complicated social organism; and it is impossible to discuss it apart from a whole of which it is but a portion. As regards the saying, "A man can no more live without land than he can without air," of course he cannot, and this fact is recognized in modem conditions, and provision made accordingly. But this is very different from saying that a man is entitled to earn his living by working on the land. By our subdivision of labour we are able to secure a total income almost reaching the inconceivable amount of two thousand millions a year. But this is obtained only by our each doing our own specialized work.

Leaving such abstraction we find that property in land is justified today by its having been freely interchanged for other property, and by the same reasons by which such other property is justified, namely, that thereby it promotes the general prosperity. 
(2) As against the theoretical arguments that land should not be the subject of property, the practical ones are very substantial indeed. In every case where it is desired to get land improved and developed, some property, fixity of tenure, or call it what we will, is essential. 'T'o take but one example. Look at the bribes offered by Canada, and other new countries, to any immigrant who will come and develop her virgin soil. So listen to Bentham, the father of Radicalism, a name once only to be whispered with bated breath in some of our ancient shrines of learning: "In England one of the greatest and best established improvements is the division of commons. In passing through lands which have undergone that happy change we are enchanted as by the sight of a new colony. Harvests, flocks, smiling habitations have succeeded to the dull sterility of a desert. Happy conquests of peaceful industry. Noble aggrandisement which inspires no alarms and provokes no enemies." When we hear talk of the stealing of land in the past, let us remember this eulogium of a contemporary on practices we now think should be condemned. And let us also remember that to-day that contemporary is the prophet of the oppressed Russian, of the subjugated Pole, and of the aspirant for political freedom in every quarter of the globe. So difficult is it for us of the present to re-open and judge transactions of the past $(e)$.

(e) So he also says, "The greater part of these great fortunes, it is said, have been founded upon injustice, and 
(3) We could multiply similar arguments indefinitely, but here we will mention two further reasons why it is undesirable to plague-mark land as an eligible form of investment.

In the first place, what we want to do is to tempt every man who has a penny saved to invest it at home, and we should do our utmost to make every home investment as desirable as possible. And so with the approbation of our greatest economists and thinkers land has always been regarded as the most desirable outlet for investments. Thus, suppose a man has $£ 10,000$ to invest. He wants it invested at home; we want it invested at home. And he sees that by buying a certain old building, pulling it down and rebuilding, he can secure a fair return for his thought, money and risk. Accordingly he does so with satisfactory results to himself, the worker, the ratepayer, and his country generally. But suppose before commencing he is met by benevolent legislators, who tell him land is not the subject of property, \&c., he may possibly be more frightened than hurt; but security gone, frightened he will be, and he sends off his $£ 10,000$ to develop industry in Japan, or the Argentines, or other more congenial

what has been plundered from the public may as well be restored to the public. To reason in this way is to open an unlimited career to tyranny. It is a permission to presume crime instead of proving it. . . To plunder great proprietors, under the pretext that some of their ancestors have acquired their opulence by unjust means, is like bombarding a city because some robbers are thought to be concealed in it."-Bentham's Theory of Legislation, p. 142. 
clime. So the old building remains standing, and joiners and builders are slack in the land $(f)$.

Then, again, what we above all want is our towns rebuilt. And how is this to be done? By a new tax on land here, a larger tax on its transfer there, and by a general policy of harass everywhere? Certainly not, but by making it and the building trade and all concerned with it a more favoured industry. We want the land jobber to be enterprising and buy wholesale, to cut up, develop, and sell retail to the builder. Then we want builders in good funds, sanguine and anxious to do business. So, when their houses are erected, we want money to be obtained on them as easily as possible. We want buyers of ground rents to be numerous and confident, so that they may get a good price, which means more capital and more building. Then we want mortgagees anxious for investments, that they may readily get in this outlying capital, again meaning still more houses, greater competition for tenants, and rents reduced to the lowest possible figure. Then we

$\left(f^{\prime}\right)$ "Quite as prejudicial to expanding production is the continuous apprehension of hostile or meddlesome legislation. When the whole body of business men are sore from disasters; when much of the industrial and commercial structure still lies in ruins, it takes but little to check the disposition again to adventure capital. T'hat little is abundantly supplied by popular apprehension of legislation unfavourably affecting money and credit. It need not be a great thing under a man's arms which will so increase his margin of buoyancy as to enable him to float for hours. It is a very small thing around a man's neck which will so diminish his margin of buoyancy-narrow at the best-as to drag him to the bottom."-Walker's Political Economy, p. 186. 
want agents and collectors ready to lend a few additional pounds on second mortgage to secure their business, and above all, we want the smaller tradesmen and investors to come forward to buy their equities so that they may press forward in their trade. Our policy, if we would improve the housing of our millions, is to increase facilities of carriage, and do everything we can to develop the suburbs of our cities. Then, as they grow up, central property becomes available for a poorer class of tenant, who benefit by the general expansion. No doubt such policy is somewhat hard on owners of these depreciating centre lots, but it is a result anticipated from the first purchase of the property. So, to accelerate such process, what is wanted is that outside money should be found by philanthropists or others with which to pull down central slums and make open spaces and gardens. The economic loss to the community is not that of their market value, but simply the loss of their intrinsic value, a value sometimes verging on a negative quantity. But it is necessary that outside money be brought in. If done through extra rates, it only checks the building of new houses, and increases congestion in one direction whilst trying to remedy it in another. Houses are only built to pay. Every penny added to the rates means a penny more required in rent. This is only obtained by limiting the supply. It does not follow that all these results will be at once apparent. Happily legislative interference is only one of the forces that go to make up good or bad trade in the building line, as in every other industry. 
Happily, we can be prosperous in spite of all the good things intended for us by benevolent legislation.

For these amongst other reasons it is obvious that so far from penalizing land in any form we ought rather to regard it with peculiar affection. Were it the sole subject of property other arguments might apply, but in England, where the income from it is not an eighteenth of the total income of the country, it is folly to unsettle laws and customs on which as a whole our mighty prosperity has been founded $(g)$.

(4) As a species of property, then, we see no reason for penalizing land, and when we come to consider it from an income-producing point of view with the idea of assessing its contribution in relation to other unearned incomes, we find that there is very little, if any, difference in the incidents of property in land and property in anything else. First and foremost, every advantage and disadvantage in every kind of property has been minutely assessed and effect given to them on their

(g) Conditions have entirely changed. As Prof. Seligman points out, "In former times after a certain point had been reached in agriculture and commerce, human ingenuity was powerless to do more than divide existing wealth, and with this fixed limit to production it is no wonder that each civilisation in turn should have attempted to secure the prize for itself. Hence the rise, the glory and the decline of nations. In future, however, in lieu of dividing existing. wealth, each 'nation which lives up to its opportunities will be able to create new wealth . . . with the growth and control of industrial capital there need be no limit to the continuous march of wealth and progress."-Principles of Economics, s. 233 .

$1)$. 
being exchanged. Is property likely to increase in value? then so much greater the value on exchange. Is it likely to depreciate? so much less is it worth. It is true this exchange is done by reference to a common standard of money, but this none the less effectually establishes a uniform level of value. The value of every class of property is determined by their value amongst themselves, land included. Therefore there is no reason for differentiating between what it should pay and what should be paid by property in other forms.

(5) But does not land owe increasing value to the action of the community? But this has been accounted for in its value in relation to other property. So far as it thus benefits, so far, as property, it is worth more. On its exchange for other property full weight has been given to this possibility. Further, it is doubtful if property in land is a whit more dependent on general prosperity than any other kind of property. All property is extremely sensitive to popular influences, doing well when the whole does well and doing badly when the whole does ill. But this rise and fall in the value of property is one of the incidents that must be taken into account when settling the relative contributions that snould be made by earned and unearned incomes generally. As between property in different forms it really has little bearing on the subject $(h)$.

(h) "The proposal to tax land values" - in the sense of unearned increment-" is simple only in appearance. It is 
(6) But does property in land contribute the same as property in anything else? This is a question of fact in particular cases. A general levelling up of income tax on all forms of property might be desirable, but this affords no reason for imposing a tax double or quadruple the ordinary levy. Reversions falling in, as between tenant and reversioner, are purely a matter of book-keeping, but yet may mean the reversioner receiving the accretions of income for a number of years in one lump sum. This should well pay income tax at the ordinary rate, as well also the money paid for fines for renewal. As a fact, our municipalities do so pay, and it may be the practice is more or less

not only difficult to distinguish in rentals between earned and unearned, and between the respective owners of these portions, but it is difficult to know when the application of the principle is to stop; and the fear of creating precedents is one of the greatest and most salutary checks on governmental interference. It has already been explained that there are large unearned elements in every species of revenue. But there can be no question that any attempt to seize them as they arise would cramp the general activity of society, and to seize them after they have been suffered to accumulate would be an ex post facto policy which would quite as effectively encourage the others not to make any such gains.

"It is, of course, assumed in this argument that the seizure is complete and differential, for such additions to property and income are, of course, subject to general taxation of an ordinary kind. There can be no question that the attempt generally to differentiate between earned and unearned income would logically end in socialism, and would destroy the efficiency of the present system. . . .

"The pursuit of this will-o'-the-wisp of an unearned increment turns the attention away from possible, though difficult, substantial reforms."-Nicholson, Prin. Pol. Econ., vol. 3,324 . 
general as it is $(i)$. So possibly the increase in the value of unused land may be due to the saving of annual accretions or income, on which also tax might be justly levied. But if so levied, it ought to be equally levied on every kind of accretion to property of every description. But this would involve vexed questions as to how decrements should be treated. But again, all such matters are best considered when determining the relative contributions that should be made by earned and unearned incomes. But, as between property in various forms, there is no reason for making any difference. Then, as making such charges involves highly abstruse and difficult enquiries, it is far simpler to judge all property by a simpler standard, and be guided by this in making the levy.

(i) In only one respect are public bodies affected by land being limited in amount and definite in location-a monopoly, as it is termed $(k)$. It may

(i) So also the large fortunes accumulated in this way may be within the mischief provided for by the Thellusson Act as to perpetuities, and from this point of view may require consideration.

(i) In modern times, again, there is no such thing as a strict monopoly of building sites. The ground rent of even the dearest plot in a crowded city exceeds the ground rents of other plots only by the value of its relative superiority. Monopoly implies absolute control of supply. Where building lots shade into each other by imperceptible gradations, with an abundant supply of the lower grade lots, we cannot speak of an absolute control of the total supply, but only of a control of part of the supply. This is not monopoly, but only the ownership of a better grade, possession of which gives a higher price but not a monopoly price.-Scligman, Shifting and Incidence of Texation, 251. 
be necessary for them to have one particular plot. At first sight it would seem what a glorious opportunity for extortion! But this is not so. By law, subject to certain formalities, now trifling, public bodies are entitled to buy any land they require at the market price. If anything is defective, it is not the principle, but the procedure. If sellers do get too much, by all means improve the practice. But because in some cases they do, this is no reason for differentiating between all land and other property. With as much reason we might specially tax all tailors because some are sweaters $(l)$.

For no reason, therefore, does it seem either expedient or just to single out land for unfavourable treatment. End meum and tuum altogether, substitute some more advanced social contract; but if not, give logical effect to the system of property as a whole. By strict impartiality, or what we term justice, we shall secure the best results for ourselves, whether workers or owners; and let us remember, there is no short cut to the millennium, not even by repudiating obligations we are bound by, nor by breaking the promises we have made.

(l) The practice now is for the price to be settled either by an arbitrator, or, if either party desire it, by a jury. A desirable change seems to be that sellers, who get less than the amount tendered by the buyers, should have to pay the buyers' costs. Many an exorbitant price is insisted on because the seller runs no risk of paying the other side's costs. 


\section{Note.}

There is a curious non sequitur between the evils condemned and the remedies proposed by some of our politicians of the hour. A "lord" has stolen land. Therefore tax every owner whether he has paid the last penny for his property or not.

A "lord" escapes paying his share of rates. Add to the burdens of all ratepayers. Some already pay too much through his not paying his share. Make them pay more.

A "lord" sells his land for too much. Worry and harass and tax those who, perhaps, cannot make it pay at all.

Land is not freely transferred. Increase old taxes, add new ones, and impose on purchasers the duty of seeing them paid. Delay every conveyance from a week to six months, add yards of red tape to every transaction, and so facilitate transfer.

The curious part is that such proposals should emanate from a Liberal Government, when every great Liberal of the past has emphatically condemned them. Mr. Gladstone, discussing the question in his quiet, stern manner, asked:"Do you mean to pay for it, or do you not? If you mean to pay for it, it is folly ; if you do not mean to pay for it, it is robbery."

"I am content to assume that a man's right to his land depends upon the same principle as your right to the coat on your back-that you have paid for it." Thus Sir William Harcourt.

So John Bright speaking of Henry George, the father of this wild school, wrote to his old friend Clarke: "I would advise you to keep to the common sense and moral sense of our own people, and not accept the ideas of wandering theorists and dreamers like the author of the book of which you have asked my opinion. I always reject the notions of men who begin their system of relief by robbing somebody."

Henry George's ethics and eloquence are well illustrated by the following:- "Though the sovereign people of the State of New York consent to the landed possessions of the Astors, the puniest infant that comes wailing into the world in the squalidest room of the most miserable tenement house becomes at that moment seized of an equal right with the millionaires. And it is robbed if the right is denied." 


\section{CHAPTER XII.}

\section{AS TO SPECIAL TRADES.}

CERTAin businesses and professions cannot be carried on except on payment of special fees and charges more or less onerous. Why a solicitor, or an auctioneer, or a pawnbroker, or hawker, more than a doctor, a broker, a banker, or commercial traveller, should be thus mulcted seems difficult to explain. As long as occupations are honest, all should be free or all should be taxed on the same terms.

But the one trade about which there is the greatest diversity of opinion is that connected with the manufacture and sale of intoxicants. Euphemistically it is known as "the trade," a convenient term by which we may well designate it.

Should it or should it not be subjected to charges special to itself alone?

The usual argument advanced in favour of such charges is that the trade has a monopoly, that is, only a limited number of individuals may deal in intoxicants. As regards the manufacture there is no limitation whatever. This results in one of two things. Either (a) the competition is limited so that the sellers can obtain more for their wares than otherwise would be the case, or (b) the monopoly is 
not sufficiently linited to affect competition to any appreciable extent.

But, assuming the first (a) is the case, it means that the man who drinks intoxicants has to pay more for them than otherwise he would have to do $\mathrm{He}$ it is who suffers by the monopoly; and why does his having to pay too much afford us, who do not, the right to step in and share the profit made at his expense?. If the doing so directly saves our purse, as it does $(a)$, it is a premium for us to charge him more that we may proportionately pay less. And suppose that the facts are more consonant with (b), and that the competition is sufficiently keen to govern the price, then it is clear that any tax that in any way increases cost will once again have to be borne by the consumer. Whether it is a tax on hops or barley, on malt. or yeast, whether it is a tax on the drink when made, or the materials of which it is composed; whether it is a tax on premises or a tax on licences, whether it is a tax on the selier in person or the thing that he sells, in every case the tax adds to the general charges that have to be provided for in the price of the article sold $(b)$.

Thus, in both cases it is the consumer who pays too much, and in both cases an outsider has no right whatever to share the plunder. No doubt it is pleasing to talk of taxing a monopoly when it saves one's own pocket, and no doubt we all delight

(a) To more than one shilling extra on the income tax.

(b) The vast fortunes made by some brewers are no different to the vast fortunes made by some soap manufacturers. Both are best dealt with by a progressive income tax. 
in a temperance propaganda that makes another foot our bills; but the fact that the sale of intoxicants is a monopoly does not justify the imposition of a single penny of additional taxation. If intoxicants are to be taxed it must be in accordance with general principles that we shall refer to hereafter.

\section{Note.}

Some of us non-drinkers and not interested in " the trade" shares would argue that more than half the sin, misery, and crime in the country is due to drink. But the moderate drinker disclaims responsibility for such excess as much as we do. Why is he to be taxed for that for which he is no more responsible than the total abstainer? But granting he is somewhat more responsible, is not a penny for whiskey and sixpence for tax somewhat overdoing a good thing? So thirty-five millions taken already from the drinker in the name of monopoly is a fairly substantial sum.

The amount levied under Mr. Balfour's Act to provide a compensation fund is another matter. It is in fact nothing. more nor less than premiums paid under a general insurance scheme. Under Mr. Balfour's Act, whilst nominally the owner of the licence is secured a freehold interest in it, yet at the same time it is subject to its being taken away at any moment for any reason; but subject to this further condition, that those who are left in possession must compensate those who have to go out. It is for this compensation that the levy is made. From a temperance point of view Mr. Balfour's Act in theory is perfect. In practice it is found to work somewhat slowly, owing to the annual lery bring too small. There are localities where licences taken away in the first year of the Act are still in existence for want of money in hand to pay the compensation. But to make the Act as useful in practice as sound in theory, all that is necessary is to increase the levy. A few lines of an amending Act to this effert would make the Act perfect. So it would hare had the further merit-it would not smash capital values and so injure innocent investors. Nor would it encounter any serious opposition on the part of the trade. 
The trade finds it no more pays to do the drink business of a district with twenty-five houses when twenty are sufficient than to do the bread trade with a dozen branch shops when ten are enough. The cost of the upkeep of the unnecessary five is a dead loss to all concerned. So further the trade would sacrifice some profit to escape the capricious action of a varying public opinion. The average public opinion over an average period they are aware they must bow to, but they would gladly join in any reasonable scheme that would let them know where they really are. No doubt it is outside of the scope of this essay on taxation to make suggestions, but there is one principle to be most earnestly commended to all who love their country, and would make it better, and it is the principle of what we may well term-levelling up. In every trade, in every house, in every man, there is room for improvement. Let us then find out what is the practice of the best in any walk of life, and seek as far as possible to make others conform to the standard thus set. By this means we shall essay only what is practicable, and so make sure progress though it is but one step at a time. Thus also we shall secure the co-operation of those most respected in a trade as well as of those who suffer from the acute competition of less conscientious brother dealers. And particularly should this be so in dealing with "the trade." All who know anything of drunkenness - and who does not?-know that it is the murderous drunkenness caused by drinking raw spirit that is so terrible. That caused by good beer or matured whiskey, \&c., may be disgusting, but does not make a man kick his wife or kill his neighbour. Thus the humane men, and there are humane men, in the trade will not sell patent still whiskey that has not been matured two years, nor pot still whiskey that has not been kept at least for four. These would welcome a levelling-up act, and few in the end would object, as legitimate profits would not be seriously lessened. What a trader above all wants is that none of his competitors shall have an undue preference. So the same system would promise most success in some of our "sweated" industries. Many a kindly master strives to give his workers the last penny possible. Would he object if all had to do the same? Now he has to conform to the meanest practices or else be driven out of the field. If by law the best could set the pace, undoubtedly much good could be done. Then also we should 
find trade unions in their right place, the good master's best friend. They would be a never sleeping watch-dog in the heart of every competitor's camp to see there was no unfair evasion. The same conditions of employment all round are what every master wants, and these secured, he welcomes every improvement that adds to the health and happiness of those whom he employs. 


\section{CHAPTER XIII.}

THE MONOPOLY OF PATENTS AND OF TRUSTS.

Here a relevant enquiry is, how far should a man's fellows secure to him the fruits of his own labour and his own brain? Simply so far as it benefits them to do so. The one question is what promotes the highest self-interest of all. If I am a party to securing to another copyright in his writings, or others do the like good office for me, it is only that in the end we hope to mutually profit by our cooperation. If I want to keep my work entirely for my own pleasure, no one has a right to compel me to give it to the world; and if I do, I know the terms on which my fellows accept it. That they secure me any rights at all is solely prompted by their desire to encourage such work generally. A part from the overwhelming difficulty of separating what a man really produces himself and what he has adapted or borrowed from others, no man can claim a thing as exclusively his own which once he has given to the world. Property in thought, discovery, or invention, is like property in everything else, simply the creation of the law. And as with all other property so created, the one dominating principle is, how far shall we benefit by giving to another exclusive rights in his own inventions? As with a book, if an invertor does 
not choose to give his discovery to the public we have no right to compel him. As long as he keeps it to himself it is his own, but if he chooses to divulge it, that is his business, and why should we be concerned to interfere between him and another who chooses to avail himself of it? If we do so it is entirely in our own interest. In the first place we wish men to work and to study to produce new inventions, for we benefit by them; and, secondly, we wish them to make such inventions as widely known as possible. But to secure these two ends it is necessary that we shall also secure to the inventor an adequate return for his labour. If this is denied him he will either be discouraged and prosecute his researches no further, or if he does he will do his utmost to darken his methods, and will keep them as far as possible a secret process. But this is exactly what we do not desire. The publicity given to each discovery makes the next so much easier that by ensuring it we accelerate our progress enormously. What then is a reasonable reward to secure a man for his inventions, and on what principle ought it to be secured him?

As many inventors are poor and humble, this indicates our first step. We ought in the easiest and simplest way possible to secure to each and all immediate rights in the productions of their brain. 'Thus we ought to give them every possible help and facility in registering their discovery, and at this stage ought to make nothing but the most nominal charges. We want to encourage inventors, and 
therefore, in the first instance, fees covering little more than out-of-pocket expenses alone ought to be taken. But from and after that time fees ought to be charged proportionate to the profits resulting from such protection. So these fees would be chargeable on profits due to any patent, or subsidiary patent, or group of patents by which such profits were secured. Further, the scale ought to be a rapidly increasing one. A patent which only secured a man $£ 100$ a year might be subjected to only a nominal fee of, say, five per cent. per annum. Patents which brought in $£ 1,000$ might well be charged ten per cent. for their continuance, whilst patents or groups of patents which brought in so much as $£ 100,000$ a year might well be charged so much as $33 \frac{1}{3}$ per cent. Practically this could be easily enforced by making every patentee keep accounts in a recognized form, and by making the payment of the proper fees a condition precedent to his recovering at law.

The main end of patents ought never to be lost sight of. Just so far as we secure to any peculiar rights, exactly so far do we wish to benefit.

Thus we wish to encourage inventors. Therefore let us give every assistance possible in the earlier and unprofitable stages, and secure to a man the fruit of his labour. Then, by drawing a large revenue from the more successful patents, we should be in a position to still further encourage inventors, and probably it would be well to earmark the whole of this fund to promote further research.

It is notorious that some of our greatest inventors 
have not received enough even to save them from a pauper's grave, and therefore we should reserve the right to recompense such inventors out of the fees received. It would not be done as a matter of right, but out of pure charity backed up by the promotion of self-interest. We wish to do all we can to encourage inventors in every class.

But equally we do not wish to confer on an inventor such exclusive rights that he is enabled to ruin all his competitors. It is progress we desire, not the creation of millionaires to live on the lifeblood of the country. Therefore every patent ought to be granted only on the terms of provision being made for the use of it by others on their paying for it a reasonable sum. This sum would have to be fixed in every case as a question of fact, and it would be fixed on the principle that it ought to sufficiently remunerate the owner without crippling his brother traders. As a body collectively we above all must avoid putting ourselves at the mercy of any single dealer, and we may encourage invention too dearly if it results in our being unmercifully fleeced by a tyranny of our own creating.

There is no hard and fast line of what we should do. On the one hand we wish to encourage inventors, and on the other we do not wish to give them any unnecessary advantages. By a system of cheap registration in the first instance, and subsequently with fees made payable in proportion to the profits earned and on a progressive scale, and by ensuring licences being granted to 
competitors on reasonable terms, we ought to be able to secure the maximum benefit for all interested, ourselves included. But the danger of monopoly granted by patent is not serious as it can be kept well under control, but the serious menace to society is the monopoly created by trusts, which in many cases are little better than combinations organized to rob the general public. Whilst in the beginning they always profess that by their united action they will better serve the public, in the result they always end by extorting every possible penny they can from their unfortunate victims. The subject is too large and serious for us to deal with here or to say more than this, if individualism cannot kill, or at least regulate trusts, trusts will kill individualism. In the past, by mere physical might, wolves preyed on sheep; to-day, by equal superiority of brain, trust mongers fatten on the community. The history of democracy in the past few centuries has been the history of a struggle against the rights created by mere rude brute force; in the future it will be that of an even more desperate struggle against the cupidity of men who by their astuteness and smartness are no less able to oppress their fellow man. The old order passeth away. Now that our old aristocracy are weak and no longer a danger, we would stamp them under foot and grind them into powder, and all the while are heedless and oblivious of the new tyranny that is rising in our midst. The snake just born we can easily destroy; a few more years and it will take more than a Hercules to destroy the monster. 


\section{CHAPTER XIV.}

THE COLLECTION OF THE REVENUE-SOME GENERAL CONSIDERATIONS.

Having determined the respective contribution that should be made by receivers of earned and unearned incomes, it would be highly satisfactory if all had to pay their proper quota in actual cash. The advantages would be great. The cost of collection would be reduced to a minimum, bureaucracy would be lessened, and, above all, economy would be promoted. Reforms would be judged on their true merits if every additional expense meant additional payment by every man in the kingdom, and popular expenditure would soon cease to be a popular cry $(a)$. But such longings are altogether too idealistic, and in collecting our revenue we must have some regard for convenience. In fact some of our economists are so hopeless of raising taxation justly that they would found their system on convenience and convenience alone $(b):-$ "The most feathers with the

(a) The same remark applies to municipal management. Would there be half the extravagance if every working man realized that when he pays seven shillings for rent nominally, in reality four to five shillings only is for rent, and two to three shillings for rates.

(b) A Government should impose such taxes as are " most easily assessed and collected."-MrCulloch.

D. 
least squarking." But this is a policy of despair, and whilst we would give attention to convenience we would do so with the idea of furthering and not encroaching upon the just contribution to which we have referred. Our overriding principle is, that as we all receive services from one another acting collectively, so we all should pay justly for them. And in this we are at one with the celebrated rules given by Adam Smith. His first rule we have already referred to $(c)$. By it he would secure what he aptly terms "equality" of taxation. It is the master rule, and his further rules that taxes should be certain (Rule II.), convenient (Rule III.), and economically collected (Rule IV.), are framed to give it effect. So in his days, taxes were so numerous and complicated that to save his Rule 1. from being a dead letter, a lengthy enquiry was necessary to establish who really paid them. Sometimes they were paid by those on whom they fell directly, sometimes by a person at the end of a long chain of transactions. So with ourselves, so far as we do not collect a man's share in cash, we must also enquire how far he does or does not bear substituted dues. We want directly or indirectly to ensure " equality," for, as Mill well says, "A peculiar tax on the income of any class not balanced by taxes on other classes is a violation of justice, and amounts to confiscation" $(d)$.

As regards our wealthier classes, we have seen that much of their contribution can be levied in

(c) Chap. IV., supra, p. 42.

(d) Mill's Pol. Ec., vol. iii. \$2. 
actual cash. Having settled the proportion which all classes should respectively pay, our enquiry is how we can collect from the less wealthy their fair share as well. This is usually attempted by putting duties on goods consumed by them, and there is no doubt that to be scientifically correct it ought to be on some commodity universally consumed by all alike. It sounds philanthropic to relieve this man on the ground of poverty, or that man on the ground of temperance; but in the end it would seem the general good would be best secured by rigorous justice.

Let other reasoning be admitted, and every class is at once prepared with unanswerable arguments why it ought to be specially exempted. Property owners can demonstrate that all modern prosperity is due to property, and the encouragement of savings. Rich merchants will deplore checking their industry. Fat lawyer's will talk of the sanctity of brains. Tradesmen will urge the claims of large families. Workers will complain of their small wages, and the sweated will have the sympathy of all. So one will rage against the way another obtains his income. The rich merchant piling up his millions out of overcharged customers, or underpaid help, will rail against property, which in its turn will rail against the Socialist and all his works.

In our contract relations with one another what we want is strict justice. The worker does not want doles nor charity, but just payment for the services he renders. The same precise reasoning which н 2 
demands from him his fair share of contribution will go far to secure him the due reward for what he does. And far be it from us to say a word to hurt our poorest, and yet in their case strict justice will serve them best. Let their stand be, "Secure me just pay for what I do, and let me justly pay for what I receive" $(e)$. Remembering then that each owes something to the general purse for the personal safety and liberty secured him, it would seem that some general small impost should be made that would have to be borne by all. This, in the case of most countries, can be well made by a small tax on all commodities imported into a country, and if made on all imports its incidence can be fairly well ascertained, as it will almost invariably fall on the ultimate consumer $(f)$. What is actually paid by each class will of course be a matter of account to be separately determined in each country $(g)$.

There are also one or two subsidiary matters that should not be overlooked when we are considering the imposition or re-arrangement of taxes.

(e) So in the case of our poorest we know that any taxes imposed must be transferred, and any tax put on them must result in a corresponding rise of earnings.

$(f)$ Other things being equal the more general a tax, the narrower the taxless field to which the persons concerned can migrate; the less general the tax the greater the chance that the tax will be shifted.-Seligman, p. 187.

(g) The advice, therefore, which the correct theory of incidence has to offer to the legislature is : choose primarily those taxes the results of which can be foretold with some degree of accuracy. At all events, take some taxes where the chances of shifting are very slight, and take, on the other 
The first is, that in our business relations with each other, certainty of law is of even greater importance than theoretical perfection, which is only to be secured by a continued state of change. Let the law be definitely settled, and we make our contracts accordingly. Let it vary from day to day, and the smart man will always make a good thing out of it at the expense of his humbler brethren. The less the alteration in any law of property, the less the man of moderate intelligence suffers. When there is only one road a child can lead us, but when there is a labyrinth of ways the clever man gets in first. Thus any change in the incidence of taxation which affects property in its capital value, will inevitably result in the small investor suffering. The rich man will find hundreds of ways of recouping himself. Who is most suffering to-day from the proposed new taxes on land, which are not even intended to affect him? The small investor. Scores and scores of such find life a burden through their mortgagees who have been frightened-perhaps also unnecessarily - wanting their loans reduced. Thus harassed, the small men have to get out as they can, and the rich men buy cheap lots. Probably pure panic, but a panic which passes the money of the poor and timid into the pockets of the strong and venturesome. Then when markets return to their fair level, it will be found the many have lost their savings, and the few have made fortunes. We had

hand, taxes which will be shifted in their entirety.-Seligman, p. 313. 
an example of this also in brewery investments, where once again the poor of their little lost much, and the rich bought back what they had sold for a half of what they had originally been paid. Nothing is so disastrous to the small investor as the benevolent intentions of legislators who try to alter laws in his behalf.

So the second principle to be remembered is that attempting therretical perfection may cause practical injustice. In many ways the incidence of rating and taxation on property is not sound, but yet this has been met by the fact that millions of contracts have been made on the basis of things as they are $(h)$. Take, as an example, tithes. A man may object to paying tithes, he may even have conscientious objections to paying tithes; but as tithes had existed for centuries when he bought his property, he bought it so much cheaper because of the tithes. He gave less and the seller took less because of such tithes. Therefore, to do justice, if tithes are wrong would involve a long enquiry in every case as to

(h) The advantages of a permanent and immutable system of raising taxes are insisted on by the German writer Prittnitz, who showed that justice might be thus secured even though, in its inception, a system were absurd and burdensome.-See Seligman, Shifting and Incidence of Taxation, p. 135 .

So the ultimate equal-diffusion theory of M. Thiers may ultimately tend to establish just contribution, but it is only when such system has been long established that it is really correct.-1bid. 135 .

As regards old taxes this may be so-he disturbs best who disturbs least-but as regards new taxes it is all-essential they should be equitable on their first imposition. 
who was the real sufferer. Then, in considering the incidence of taxation on property, let us remember that apparently it may not be very satisfactory, yet if of long standing as between respective contending interests, it may have been fully taken into account when settling the capital value. The one thing to be avoided in levying taxation is the virtual re-making of contracts between individuals. If two men are mutually interested in certain property, and one of the terms of their agreement is that one shall bear all the outgoings and the other shall receive his share net, it is perfectly certain this arrangement has been made only for very solid value or consideration given in exchange. To-day the one may benefit, to-morrow the other, but the possibility of the happening of either event has been fully taken into account in settling the original contract. If two men after long bargaining make a contract, it may be assumed it is made to please them both. For the legislature then to alter the incidence of taxation to benefit one at the expense of the other, is simply making one a present out of the pocket of the other, and is neither just nor wise.

And in conclusion, there is one paramount reason why the strictest justice should in every case be observed. To-day our power is rightly vested in our people, but the attempt to gain their suffrages by specions and faliacious arguments is almost overwhelming. Democracy as an institution is perfectly sound so long as it can only give effect to its will through honourable and enlightened representatives. 
But naturally every democracy is prepared to be bought by the highest bidder, though every true man would scorn to be such bidder. As long as democracy can act only through men of probity it probably secures the best form of government the world has known; but let men of doubtful integrity or mental limitations secure supreme control, and it can ruin an empire in a shorter time than any other form of rule of which history tells us. Things perfectly natural for the masses to demand ought to be impossible for any statesman to grant. Ignorance of economic laws is not only pardonable but to be expected in the many, but one who would direct the destinies of his country ought to know all that is to be known on such a subject. With him ignorance is no excuse. His duty is to learn. 


\section{CHAPTER XV.}

THE COLLECTION OF THE REVENUE-SOME PRAC'TCAL CONSIDERATIONS.

WE have given reasons why a small impost should be made that should be borne by all, and to this end have suggested that a small uniform tax could be justly imposed on all commodities imported into the country. How would it affect us in the British Isles if a uniform duty of five per cent. was thus made general? It would be a tax on food, and on raw material as well as on manufactured goods. Is there any valid reason why any exception should be made?

And first, as regards food. We have seen that a tax in the nature of a poll tax for the protection of life and liberty ought to be paid by all. Roughly, our food imports are about $£ 240,000,000$ a year, on which five per cent. would be $£ 12,000,000$, not more than that now raised by our present miscellaneous taxes. Thus, with a national bill well over $£ 150,000,000$, this amount is by no means excessive, granting it were all paid by the people of this country strictly per head. No doubt the richer man, either directly or indirectly, would pay far more than he would do if it were a mere capitation levy. So to suggest that such readjustment of taxation 
would mean the bringing back the "hungry forties" is obviously an absurdity; were the whole tax additional it would not mean so much as a penny on ten twopenny loaves.

Then, as regards the effect of such a tax on raw material. About this also there is much exaggerated talk, but its effect could not be serious. Thus, take a tax of five per cent. on cotton. At $8 d$. a pound it would not be a halfpenny, and as such cotton would manufacture into goods worth anything from $1 s .6 d$. to $2 s$. $b d$., the addition of a halfpenny would be almost inappreciable. Nor would it be serious if it were inflated, and.by the time the consumer had to pay it, it had swollen to three farthings. If necessary, a corresponding rebate could be allowed on export, but it is doubtful if it ever would be really wanted.

As regards the five per cent. on manufactured articles, it would probably have to be paid in the end by the ultimate consumer, and obviously could be imposed without doing injury to anyone.

What we want is that our duty should be on no one article, and simply as a fiscal measure it is very desirable that a duty should be uniform and general. If the country has to raise thirty millions by customs, divide it amongst all our imports. If forty, equally so divide it. Our present system has many of the evils of protection, and none of its advantages. The Dutch, who rightly claim to be free traders, put a uniform tax of five per cent. on everything they import. There is no especial magic about five per cent., but there is much sound sense in having a uni- 
form charge. And if we were to put a uniform tax of five per cent. on all our imports, the amount would be about what we now collect from our customs generally. It really would not seem that any serious objection could be taken to such general tax, and if it were the means of effecting a compromise on the subject it might be invaluable. Here are the facts. A large number of us prefer free trade, and as many want tariff reform. Well, let us meet one another half-way. Theoretically it is not just for either of us to rigorously enforce our views on an unwilling minority. As free traders we now have to raise an amount equal to five per cent. on our imports, and so there cannot be any serious infraction of our principles if we adopt a uniform system, and as tariff reformers we may be satisfied if we secure some of the benefits we anticipate will result from such collections of the revenue.

\section{Note.}

Chiefly because free trade makes for purity of trade, and for other secondary reasons I have given in my former volume (Liberty and Proyresss), I incline to free trade. At the same time, in a uniform levy such as above, I see nothing inconsistent with such principles, and certainly nothing threatening to our prosperity. What threatens our prosperity is our extravagance and excessive taxation. So also, 1 think, as free traders, we might try to really master the arguments of tariff reformers, and then our refutation (?) of them would carry more weight. Their fundamental position is, that we shall be more prosperous if our unemployed make goods than if we buy them from foreign producers, however cheaply. Thus to buy, say, 30,000 foreign doors might mean a saving to the consumer of $2 d$. a door, and to the country of $£ 250$ on the lot. But, at the same time, if 
our own mills are running half-time it might mean the loss of the work of a thousand men for a month for more than an hour a day, or a total loss in work undone of $£ 1,500$, a net loss to the country of $£ 1,250$.

To this the free trader replies, that goods are paid for by goods, to which the tariff reformer rightly answers, not directly. Thus the tariff reformer asks, what single article would Germany cease to buy from us because we put a tax of 5 per cent. on her goods? And again, he rightly says, not one. Germany does not buy a single thing from us but what, in her own interest, she has to buy. Why ultimately over long periods, and for large amounts, goods do ultimately tend to pay for goods-and then only when settled up in the Clearing House of the world-is, that if we restrict imports we still desire to be paid for our exports; and if we restrict our import of commodities it means we must increase our import of gold. But so far as we import gold it accumulates in our country, and depreciates in value. As gold so depreciates prices rise, and if the rise is 5 per cent. it would mean that goods formerly sold for 20 s. would now be 21 s. Hence, if a foreign trader when there was no duty could afford to sell at $20 . s$, he can afford to sell at 21 . less 5 per cent. when there is a duty of this amount (1). Of course it by no means follows that a duty of 5 per cent. would result in a corresponding depreciation of gold, still less that it would instantly be shown by statistics. It must not be forgotten that the price of the day is the resultant of many forces, exactly as good and bad times are the result not of one cause but of many. When all the forces act in one direction we have the extremes which become historical. On the other hand, happily one force is generally neutralized by others, and a more equal state is preserved than otherwise would be the case. But in the end this influence of gold on trade tends either to neutralize the tariffs, or else, on the tariffs being continually raised, results in centres of trades becoming centres of isolation with a considerable loss of energy to all concerned. But when we speak of goods paying for goods, it is only true so far as it is brought about by

(a) With so much thuncler in the air, whether it might not even be wise to accumulate bullion, and so for a time negative the effect of such excess of imports of gold, might well form a question for the serious consideration of our politicians. Of course it means a loss of interest on gold thus hoarded. 
this general operation of the money exchange markets of the trading world.

As a practical question it is doubtful if a duty of 5 per cent. would necessarily mean any curtailment of trade at all, and in the meantime it would give some margin of security to home manufacture. The tariff reformer's argument in this respect is, that modern conditions of manufacture are such that, to pay, mills must be worked to their maximum capacity, (r) otherwise suffer loss. Thus if a mill is equipped to turn out 20,000 units, it would mean that whilst it might just clear itself with 17,000 units produced, all above would be profit. If, then, their home trade would only absorb 19,0010 units it would still pay its owners to turn out the extra 1,000 , if they got little more than the actual cost of the raw material and bare wages. Standing charges, interest on capital, and such like expenses could be disregarded. But it would not pay them to spoil their own market, and hence their willingness to sell at any price away from home. We have a parallel case to this in that of our millers, who will often sell their overstock at give-away prices, but never to their own customers. But what is the result of foreigners so selling to us? It produces the facts shown by the case of dours we have mentioned. The consumer gets them for $£ 250$ less, but our own works have to run half time. On the other hand, there have been plenty of instances where some of our home manufacturers have bought dumped goods which have enabled them to secure foreign orders through the very cheapness of the dumped raw material they have purchased. But granting all this, the tariff reformer not unfairly argues: "It is hard on our home producer to suddenly find all his arrangements disorganized because some foreign maker has a stock he must clear." Tariff reformers say, give such makers a margin of ten per cent., and then if the foreigner wants to dump he will be forced to give us something substantial. Thus, once again referring to our example of doors, euppose the normal price to be $5 s$, then the foreigner cuts just low enough to secure the market, say at $4 s .10 d$. But, duty or no duty, he will have to sell at 4 s. 10d., or give up the business. But if the duty is 10 per cent., this means be will have to pay the $6 c l$. duty himself or, in other words, sell at $4 s .4 \%$. The duty paid will no doubt figure on the invoice of the buyer, but it will none the less be paid by the seller of the goods. And this is what 
the tariff reformer means when he says that in certain cases the foreigner will pay the duty (b). However, the subject is too large to be pursued further in its numerous ramifications, and I think I have said enough to show that without jeopardizing the prosperity of the country, as free traders we may reasonably meet the tariff reformers to the extent $I$ have named. Or if the tariff reformers should be in power, they also might consider the prejudices of their compatriots, and limit their proposals in a similar manner.

(b) As a temporary result, the effect may be even more marked; thus in the opinion of M. J. B. Say: "A tax on any article, when followed by a rise in price, falls on the consumer only in part; for increased price means diminished consumption, and smaller demand means lesser profits. Thus the producer will bear a part of the tax."Traité d'Economie Politique, Sth ed., p. 562.

But this statement does not sufficiently take into account the consequent lessened production. 


\section{CHAPTER XVI.}

TAXATION IN ITS MORE PRACTICAL ANPECT.

How far are our preceding conclusions applicable to modern conditions? To-day we have a national bill to meet which is somewhere about $£ 165,000,000$; how can we do it?

We will not attempt accuracy of figures, but take amounts which approximate only to actual facts. So, as regards our total national income, without making any estimate of its present amount we will simply assume that it is divided into not dissimilar proportions to those given by Mr. Chiozza Money for the year 1905. We remember his figures were $£ 1,710,000,000$ for the total income, of which $£ 880,000,000$ were taken by those receiving less than $£ 160$ a year, and $£ 830,000,000$ by those receiving more. Thus it would seem that if the taxes were contributed in direct proportion to the income received, the former should contribute about $£ 84,000,000$, and the latter, the well-to-do, about $£ 81,000,000$. We particularly mention this in relation to the suggestion that there should be a uniform tax of five per cent. on all imports, food included. With a tax of five per cent. on food imports, estimated at $£ 240,000,000$, we should only raise $£ 12,000,000$, which, if the people paid the whole, would not nearly approach the above sum. In fact it would hardly amount to their theoretical 
share of the poll tax that should be levied on all for simply ensuring personal protection. But we are not here advocating proportional taxation, but simply indicating what it would result in. Rather we desire a fair system of progressive taxation.

Again, we may assume our total imports to be about $£ 600,000,000$ per annum, and one merit of having a uniform tax of five per cent. on everything is, we need not attempt to distinguish between particular items which go to make up the total. By taking all the imports together we shall avoid any difficulty, for whatever the money is spent on, five per cent. will go in duty. Nor will any serious error creep in if we assume that probably all imports will be purchased in proportion to the income of the buyers. Some will buy them in one form, some in another, some direct and some after many intermediary transactions, but in the end the tax of five per cent. will be paid by all the ultimate buyers alike $(\alpha)$.

(1) This is only an approximate statement. Thousands of pages have been written to show how such taxes really are borne, but roughly, we shall not be far wrong if here we credit the consumer with the whole. A masterly exposition of the subject is that by Mr. Seligman in his work on The Shifting and Incidence of Taxation. On page 116 he admirably epitomizes Adam Smith's reasoning as follows :"If we sum up Adam Smith's doctrine of incidence, we see that taxes on wages, taxes on profits (except the tax on interest), and taxes on necessaries are always shifted. On the other hand, taxes on land and taxes on luxuries always stay where they are put. The classes of society who bear all the taxes are thus primarily the landowners, the rich consumers, and, to a certain extent, the lenders of capital."

With these conclusions Mr. Seligman hardly agrees. They 
Thus, if the five per cent. on the total imports yielded $£: 30,000,1000$, the people class should be credited with about $£ 16,000,000$ of it, and the wellto-do with the balance of $£ 1+, 000,000$. To make up their fair proportion of the whole, the former should still pay a considerable amount in addition. This to some extent is done by the tax on intoxicants, which yields, say, £36,000,000 a year. We have seen this tax is not quite satisfactory, and balancing items should be found to fall on those who escape such payment. The usual alternative drinks are tea, coffee, and cocoa, and as a matter of simple finance and simple justice, these should also contribute. Thus this affords a good reason for retaining the tax on tea. At the same time, it is at present levied in the most unjust way possible, namely, by weight. If we were to collect the revenue by a duty on value we could relieve our poorest class considerably, and give some effect to progressive taxation. At present we want to raise $£ 6,000,000$ of revenue from $£ 10,000,000$ of tea which would be done by an ad valorem tax of about 66 per cent. on the cost. Then, whilst the poorer would get their tea cheaper, the balance would be made up by those with the larger incomes. Similarly, to some extent the taxes on tobacco might be re-arranged on a percentage basis; but before doing this it would be well to consider how far the relative taxes would be borne by the two great classes of income receivers.

are based on a too purely theoretical condition of a free competing society.

D. 
A further source of income should be the charge made for patents. This we will not include here, as it seems well that such receipts should be ear-marked to promote further invention and research.

As regards the Death Duties, Income Tax, House Duty, Land 'Tax, and non-tax revenue, we may take the figures very much as they now stand.

By adding together these respective items, we get a national budget much as follows:-

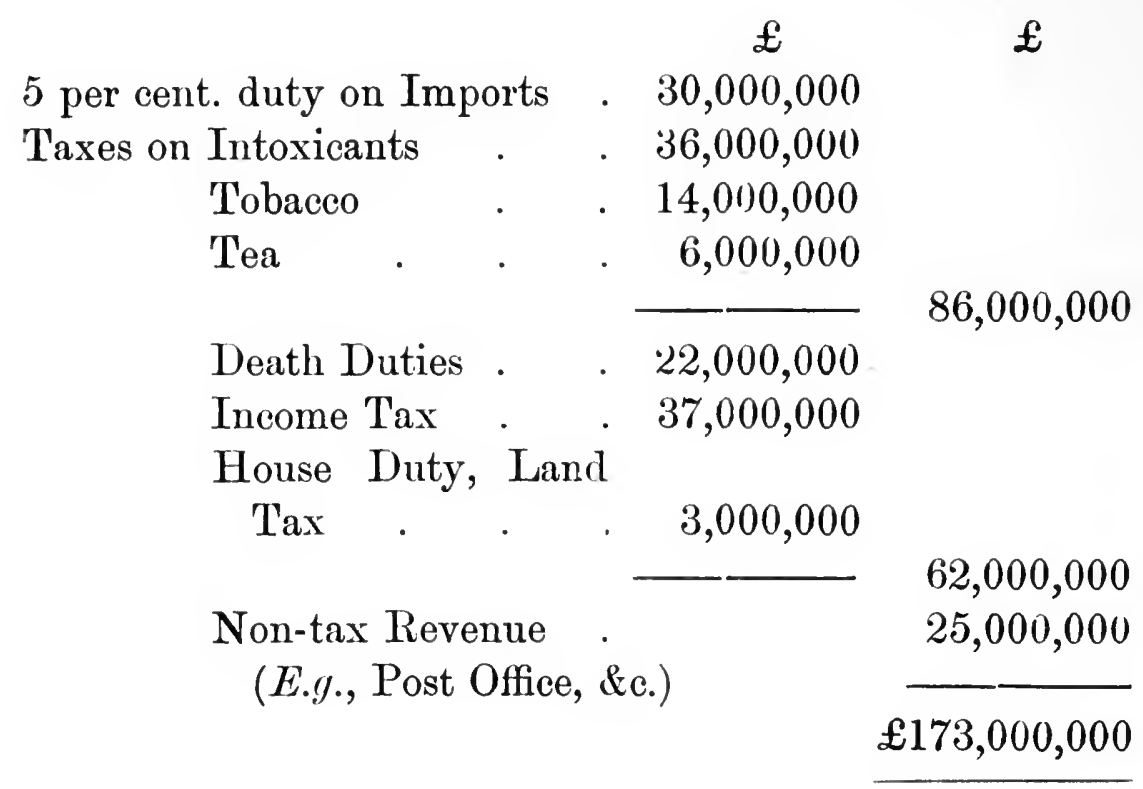

Let us examine how such taxes would be respectively borne by the two classes of income receivers.

Of the $£ 30,000,000$ received from imports, we have seen $£ 16,000,000$ should be credited to the people class.

Of the $£ 36,000,000$ received from intoxicants, perhaps as much as two-thirds should also be credited to them. 
By taxing tea and tobacco on value instead of by weight, the amount paid could be made to approximate pretty closely to income generally. However, we will assume that of the tobacco tax as much as $£ 8,500,(100$ would be paid by the non-income tax class, and $£: 3,500,000$ of the tax from tea.

Thus the amount paid by the two classes of those with incomes over, and those with incomes under, $£ 160$ a year, would be as follows :-

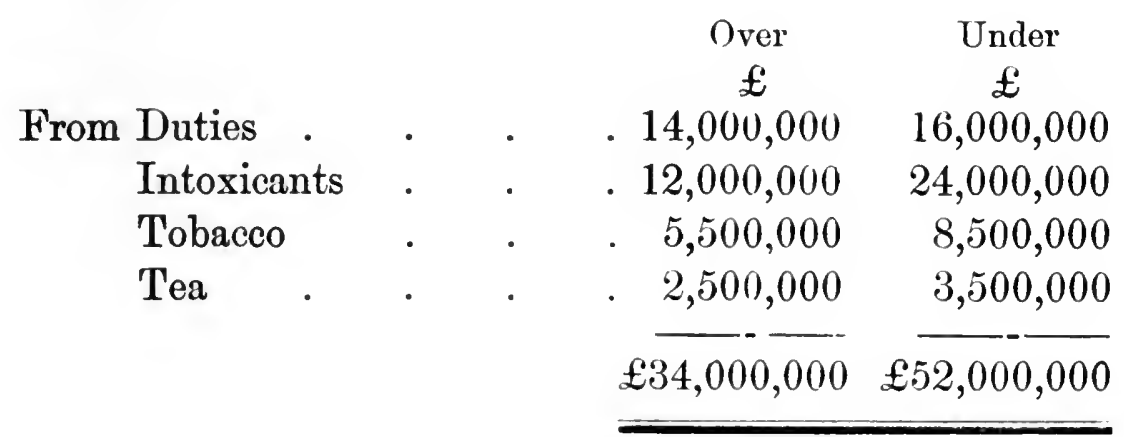

But those with over $£ 160$ a year have to pay $£ 62,000,000$ in addition for death duties, \&c., i.e., have to pay $£ 96,000,000$ as against the $£ 52,000,000$ by those with under $£ 160$ a year. But the $£ 96,000,000$ are paid by a class whose total income is $£ 830,000,000$, whilst the $£ £ 2,000,000$ is paid by a class whose total income is $£ 880,000,000$. In other words, those with incomes over the $£ 160$ a year would pay just double what those do with incomes under $£ 160$ a year, a result not too favourable to the wealthy classes. And this is what we might expect. Those who pay a tax on their income have, to a large extent, to also pay the tax on what they buy with that income. Were the 
5 per cent. Customs duties balanced by equally general 5 per cent. Excise duties, this would be so universally.

Then it will be observed that these items of taxation largely lend themselves to differentiation by steps, and the principle of progressive or graduated taxation could be given full effect to.

It may be objected that these taxes provide for no special contribution from luxuries per se. As we have before observed, there is no luxury like that of a good income, and if incomes are taxed progressively they ought not to be taxed in other directions as well (b).

So by thus simplifying our system of taxation we could with advantage abolish every other impost and much vexatious red tape at the same time. Let us take a few items. The serious one to omit would be the stamp duties, which bring in about $£ 8,000,000$. There are stamps on deeds, stamps on bonds, stamps on contracts, stamps on notes, receipts, drafts and what not, all of which harass the commercial men, are a nuisance in business, and should be ended. They entail the waste of labour of a double set of clerks, of officials who stamp and supervise, and of the merchant staff that gets the stamping done. One of the items in such stamps which brings in

(b) A possible exception might be motor cars, for which special services in the way of road repair, \&c., are needed, and for which perhaps their owners should pay. But all said, it seems a doubtful policy to enquire how an income is spent. The larger the motor, the larger the income, usually, and therefore the larger the taxes paid. 
$£ 2,000,000$ is for licences paid for by hawkers, auctioneers, solicitors and others, and for the use of armorial bearings, and on cards, \&c. These have no justification. When we collect from our rich class $£ 96,000,000$, why trouble over odd guineas? Then why should any have to pay a special tax for carrying on a legitimate business?

So as regards real estate. Why should a man who makes the furniture in a house be able to sell and transfer it without a tax, but the man who builds the house be compelled to pay a fine for his enterprise? Half the difficulties connected with modern conveyancing are due to taxes which a purchaser has to see have been paid, and which he can do only when advised by an expert.

But as for the red tape involved in these and all similar matters, it is as irritating as unnecessary. What we want is to put all our system of taxation on broader and simpler lines.

If in doing so we can effect a conpromise between the hard-headed, clear, common-sense men of all parties, we might do much to restore the confidence so all-important to commercial enterprise. And this established, we should find that many of our problems of unemployment would soon more than half solve themselves in the general prosperity that would result $(c)$.

(c) A tax on imports might settle our Irish difficulty. As an integral part of our United Kingdom they would have free trade with us. This would be equal to a five per cent. preference, and might compensate them for not having Home Rule. 


\section{CHAPTER XVII.}

\section{CONCLUSION.}

WE have not thought it any part of this brief enquiry to touch on the question of expenditure. But this is even a more serious matter than the actual collection of the revenue, and we cannot do better than conclude with the wise words of Prof. Nicholson, when he says:- "If we take a broad historical survey we find that one of the most frequent causes of the ruin of nations is excess of public expenditure, whilst there is not a case on record in which the parsimony of the Government can be accused of national disaster" $(a)$. No one has more eloquently and truly described the calamitous effect of extravagance and the waste of money than our late premier, Mr. Campbell-Bannerman. "Shall I recite," he says, "some links in the dismal and ugly chain? Dear money. Lower credit. Less enterprise in business and manufactures. Therefore, reductions in wages, increase of pauperism, nonemployment. The fact is, sir, you cannot pile up debt and taxation as they have been piled up without feeling the strain in every fibre of society." So our present premier, Mr. Asquith, speaking at

(a) Prin. Pol. Ec., Vol. III., 2555. 
Cambridge, as truly said, "if he were now asked what he considered to be the most serious burden upon the industry of Great Britain his answer would be, not tariffs, not foreign competition, not dumping, but the enormous and progressive increase in the amount the State took and was taking by taxation and by borrowing out of the pockets of the people of this country" $(b)$. And this is but the impress of the practical politician on the profound reasoning of our economists, for, as Prof. Nicholson again so truly remarks $(c)$, "there can be no doubt that historically in countries that are burdened with excessive taxes, apart from the share supposed to fall on labour, there is an additional burden due to the contraction of enterprise and accumulation."

So again there is the same consensus of opinion on the folly of driving capitalists to seek investments in foreign lands. "While capital has gone oversea in a never-ending stream, the people whose united activities produced the commodities embodied in that capital have remained poor for lack of the proper investment of capital at home. Large sections of the British people have unconsciously worked for the benefit of the foreigner and the British colonist, never realizing that their own country sorely needed all the capital that their

(b) Precept and Practice. $\mathrm{He}$ is responsible for running up the expenditure of the country from 147 millions to over 160. Hence the necessity for novel ways of raising the revenue. But "the Liberals have ceased to represent the direct taxpayer of the country."-Spectator, March, 1910.

(c) Vol. III., 299. 
labour could create... A generation ago were born hundreds of thousands of British children who for lack of the full employment of British capital on British soil are to-day creatures of the abyss" $(d)$.

Thus forcibly writes Mr. Chiozza Money. But if we want people to save at home, for capital is savings and savings only, and if we want people to invest at home, is it not the merest common sense to offer them every possible advantage, and every possible facility? Is it an encouragement to people to save and invest at home to plague-mark one greatest outlet for investment-the land, and to tax and re-tax and super-tax the investment when made? And does the end justify the means? It only shows a most lamentable deficiency in knowledge of economic laws. Millions and millions are being wasted in the establishment of more and still more public offices and officials. If the money now being wasted were spent in reduction of the national debt, something might be said for the policy. It would be an example of the one possible way in which taxation by enforcing involuntary saving might add to the general prosperity. A few extra millions so spent every year would be a benefit to every worker in the country. Consols would certainly rise, and with them all gilt-edged securities in sympathy. These again would act on commercial securities, to again react on securities of every description. But a rise of any security, the increase of any margin, means that the working owner, as distinguished

(d) Riches and Poresty, p. 148. 
from the sleeping lender, would have more funds. With these to the good he would be more enterprising, employ more men, and trade generally would improve. Then we should do something actually and in fact to make employment. It is not bureaus and officials that are wanted but the employment itself. Just as the household is happy and prosperous and contented when the master is firm and hard-headed, so is the country. Maudlin sentimentality is as fatal in the one as in the other. But, happily, good and bad times, as we have before observed, are the resultant of many forces, of which good and bad executives are but one, and we can hope for the best. Our country is sound, our workers some of the finest in the world, and the froth is on top. The one danger ahead is the ovorwhelming desire to do something great and good at other people's expense. As individuals we mostly spend our own money fairly wisely; let us be as careful in spending that of other people. The law of life is the law of self-denial, and each has to shoulder his own burden. Many a parent would bear that of his children only to fail disastrously, and in society at large we can do far more for suffering humanity by enforcing duty than by evolving schemes of charity - which will probably aggravate the eviland for which we intend our neighbours to pay. "Exercised at a man's own expense, liberality may be or may not be, according to circumstances, a virtue; exercised at the expense of the public, it never can be anything better than a vice . . . Exercised at a man's own expense, it is at any rate dis- 
interestedness; exercised at the expense of the public, it is pure selfishness; it is, in a word, depredation" $(e)$.

Thus writes Bentham, the pioneer of freedom, the greatest and wisest champion of the people the world has ever known. And he wrote in the interest of the people themselves. He knew the sorrow and privation and suffering caused by quack vendors of infallible political cures, and he knew and taught that there was but one road to national prosperity and national happiness, and that was to find out what was one's duty and to do it. No man is ever happy who lives a life of neglected duty, and that nation will be most contented which is most insistent on duty being done.

(e) Bentham, Vol. II. p. 437. 
BY THE SAME AUTHOR.

\section{LIBERTY AND PROGRESS.}

¿vo. pp. xvi and 340 .

Price 9s. net. (Inland postage, 5d.)

\section{CONTENTS.}

\section{Part I.-The Employed.}

I. Liberty.-II. Liberty and its Limitations.-III. Individualism. IV. Services rendered.-V. Value of Services generally.VI. Our Underpaid.-VII. Our Fairly Paid._VIII. Value of Services as practically determined.-IX. On Price as a Measure of Value.-X. Our Overpaid.-XI. and XII. The Rights of Joint Producers.-XIII. The true Functions of Trade Unions. - XIV. to XVI. Property: its nature, incidents, limitations and varieties.-XVII. Individualism and Compensating Forces.

Part II.-The Principles of Employment.

XVIII. Our Subject stated. - XIX. Conflicting Interests.XX. Good and Bad Times discussed.-XXI. Changing the Channels of Employment. - XXII. State as Organizer of Lahour.-XXIII. State as Finder of Work.

Part III.-Our Underpaid and Tnemployed.

XXIV. General Considerations. - XXV. Nature's Laws and Parental Responsibility. - XXVI. Nature's Laws and Thrift. - XXVII. Nature's Laws and Organization. XXVIII. The Residuum.-XXIX. Our Unemployed. XXX. The Consolidation of our Poor Laws. - XXXI. Further Considerations. - XXXII. Poverty in relation to Crime. - XXXIII. The Housing Problem. - XXXIV. Progress.-XXXV. Conclusion. 



\title{
LIBERTY AND PROGRESS.
}

\author{
PRESS NOTICES.
}

"The task which Mr. C. Y. C. Dawbarn has set for himself is a rational defence of the gospel of individualism. His treatment of the subject is positive, constructive, scientific. $\mathrm{He}$ concedes that individualism is not the only doctrine claiming. attention; but it is here, it promises most to humanity, it is in harmony with nature's laws, and it is entitled to a fair trial before it is pronounced inadequate to produce liberty and progress. Based upon the principle of "payment for services rendered,' it is honest, and it makes 'no assumption of virtues non-existent.' Quite as great danger to society arises from the classes of the overpaid as from those of the underpaid. The business of society is to guard against privilege and to preserve equal opportunity for all. The resulting struggle for existence, as in all nature, will be severe, but it will likewise be beneficial. The logic of the book is remorseless, confessedly so; and many conclusions will communicate more or less of a shock to minds trained in modern humanitarianism. His view is the long view, and to his mind to preserve and to increase the number of the unfit is not to be philanthropic but merely to increase the social burdens of the future. Whatever the reader's point of view, the perusal of this book will prove a mental stimulus and will contribute much to a calm and sane view of the great economic problems of our modern life."-Political Science Quarterly.

"A defence and exposition of individualism, in principle and in practical application to social and political questions of the day. Mr. Dawbarn writes throughout in a fresh and suggestive way, and bases his views on many quotations-in notes at the bottom of the page-from Bentham, Fawcett, and Mr. F. A. Walker, the Massachusetts economist."-The Times.

"Among recent books which Anti-Socialists may be recoulmended to read are Mr. Dawbarn's 'Liberty and Progress' and Mr. Headley's 'Darwinism and Modern Socialism.' Mr. Dawbarn looks at the subject essentially from the abstract point of view. $\mathrm{He}$ has evidently been largely inspired by Bentham, and he has usefully reproduced in footnotes some of the most valuable of Bentham's sayings. The following, for example, if only its 
truth could be grasped by the public generally, would serve to dispel many of the most popular of the Socialist theories: 'Poverty is not the work of the laws: it is the primitive condition of the human race.' Mr. Dawbarn elaborates this fundamental truth, and points out how miserable is the lot of man in the unaided tight with Nature. It is by the organisation of labour and by the use of machinery that the world is able to create sufficient wealth to bring comfort, and even luxuries, to millions whose primitive parents were naked savages. The portion of this huge product of wealth which the capitalist and the organiser of labour retain for themselves is a mere fraction of the total. It seems large when compared with the share which goes to any individual unskilled worker, but it is small in comparison with the amount which the unskilled workers collectively draw. Yet without the capital and without the organisation these unskilled workers would be unable to support themselves. Even if the employer gave up his whole profit, it would in many cases add no appreciable sum to the wages of his workpeople. It is more often possible to improve the condition of the worker by raising the price of the product, but this method is not always available. The building trade is a case in point. The various Trade Unions connected with this industry have in the last twenty years very greatly raised the cost of building with a view to benefiting their own position. Yet there is no trade in the kingdom at the present time suffering so much from chronic unemployment as the building trade. This illustration is of course not conclusive, and it shows the danger of the assumption that the raising of the price to the consumer will necessarily benefit the producer. Broadly speaking, the improvement of the position of poorer members of the working classes, though it ought to be a primary object of all social effort, cau only be secured by increasing the efficiency of labour. To this end three factors contribute,- the increase of capital, the improvement of organisation, and the improvement of the labourer himself. Unfortunately the efforts of the Socialists are directed towards the weakening of all these three factors. They denounce the capitalist as a thief, and discourage saving, which is the only method of increasing capital; they are jealous of the skilled organiser of labour, and make his task as difficult as possible; and finally, instead of encouraging the individual labourer to improve himself as an industrial unit, they preach that he should give as little value as possible for the wages he receives."-Spectator.

"Mr. C. Y. C. Dawbarn, M.A., treats in 'Liberty and Progress' of the principles of employment, the employed, and the unemployed, with regard to the special conditions and 
problems of the present day. He offers no new gospel, as he puts it, and makes no new suggestions, but attempts what is, perhaps, something more difficult in applying 'old principles to new conditions.' In a word, old truths are re-stated and forgotten teachings are re-enforced in Mr. Dawbarn's work."-The Westminster Gazette.

"Mr. Dawbarn pursues the consideration of modern economic problems upon thoroughly independent lines; he is not the adherent of any militant party, and if he is under the prepossession of any individual influence, it is that of Bentham, from whose writings his pages are freely studded with quotation. His strongest inspiration is a trust in the moral efficacy of individualism as the essential motive power of human progress. To this the security of property is a necessary corollary, and the author deals trenchantly with the dangers of an undiscriminating appeal to the instincts of rapine which may be aroused in any democracy. 'Envy needs little cultivation to become a terrific engine of evil, and a Frankenstein monster can well be made of less promising materials than men thirsting for the good things denied them, as they are told, by the wickedness of other people.' Mr. Dawbarn, none the less, is prepared to accept public intervention in such matters as the limitation of working hours, the fixing of a minimum wage, and especially the control of great trading corporations. 'Individualism must destroy trusts, or trusts will destroy individualism.'"-Pall Mall Gazette.

"All the signs of the times point to the near future as the battle ground not between Conservatism and Radicalism but between Individualism and Socialism. The Budget controversy has brought us to the very verge of the conflict. Politicians of a certain type are playing with the fire that threatens a general conflagration in which all private property will be thrown into the melting-pot. It is impossible to tell with whom the ultimate victory will remain in this struggle between the wise selfishness of Individualism and the barrenness of Socialism. But it is of the highest importance that we should seek to understand the questions at issue. Mr. Dawbarn steps into the thick of the fight. In his defence of Individualism he strikes new ground, or rather, we should say, he sheds fresh light on the fixed principles of political economy. His book touches us at every point of our social relations, and his style and treatment of the subject go far to discredit the theory that everything connected with economics must necessarily be dismal and boring. The author makes out a trenchant case for Individualism, which, he maintains, is freedom for every man to work out his own salvation, giving every other man 
liberty to do likewise. Mr. Dawbarn thus defines the functions of the State.

'Let it (the State) hold an even hand between all, and see fair play by and to all. Let it discharge its sacred duty as trustee for children, to see their liberties are not infringed, and compel all to discharge those duties to them they have voluntarily incurred. Next, let it make wise laws to determine what is just payment for services rendered, and see they are made equally effective in ending overpay as in increasing underpay. Lastly, let it rigorously enforce the law, and not allow the strong to oppress the weak, the knave to cajole the fool, nor the cunning to take in the innocent. Whatever is done under the flag, let the flag support, and let it make secure a man's life, limb, and property, and as much scorn a lie for public as for private gain.

Within these lines there is endless scope for the perpetuation of that sane Individualism which we believe still appeals to the common sense of the vast bulk of the community. With such a programme we can afford to await the final condennation of those politicians who, with all the tricks of the platform, are now appealing to the worst passions of the mob. . . . Put in a nutshell, Mr. Dawbarn's book emphasises the wholesome theory that a great nation and a great Empire can only be built and maintained by the best and highest exertions of the individual when allowed all that liberty of action which yields precisely the same liberty to others. The function of the State is that of the umpire at a game-to see that all the rules are observed, that no man gets an unfair advantage over another, and that full scope is allowed for the varied individual characteristics of each member of the team. The volume deals a staggering blow at the pretensions of present-day Socialistic writers." -The Globe.

"Mr. Dawbarn's defence of individualism and laisser faire is interesting if ouly for the mass of quotations from halfforgotten authorities, such as Bentham, Fawcett, and Buckle, which it contains, and many of which will be found most serviceable in the Budget controversy. Nothing is more remarkable, indeed, than the gulf which has opened between the Radicalism of the past and the Radicalism of to-day. Bentham was the founder of that old Radical Party to which Cobden belonged, and which taught that the true road to collective happiness is selfishness in the individual. But after the Limehouse speech what would the modern Radical make of apothegms like these?-

'A long time has been necessary to carry property to the point where we now see it in civilised society, but a fatal expe- 
rience has shown with what facility it can be shaken, and how easily the savage instinct of plunder gets the better of the laws. Governments and the people are in this respect like tamed lions, let them but taste a drop of blood and thoir native ferocity revives.

'To plunder great proprietors under the pretext that some of their ancestors have acquired their opulence by unjust means is like bombarding a city because some robbers are thought to be concealed in it.

'Liberality exercised at the expense of the public can never be anything botter than vice. . . Exercised at a man's own expenso it is, at any rate, disinterestedness; exorcised at tho expense of the public it is pure selfishness; it is, in a word, depredation." "-Daily Mail.

"Much food for reflection will be found in Mr. Dawbarn's scholarly, work, which is particularly opportune in these days when 'the air is full of reforms-well-considered reforms, and reforms not considered at all,' and many, we think, will agreo with his suggestion that the greatest and most wanted reform of all is to reffect more. He holds that real progress is not to be achieved by making a clean sweep of every existing institution, when we shall probably have nothing but a ruin for our reward, but by trying to appreciate what existing conditions really are, and then proceeding by steps. On these lines his book is written. . . Haring cursorily sturveyed the various forces which govern society, on the true appreciation of which all reforms must depend for their suceess, Mr. Dawbarn comes to the conclusion that indivitualism is the only practicable system. 'Freedom and individuatism anc e'o. ely knit together, freedom and individualism are one, and progress is the child of both. Our liberty we love, our progress we desire, and we close our inquiry with the happy ronscionsness that the moro yealously we maintain the one the more effectually will the other be maintained. Liberty and progress, inseparable and undivided, we blazon both the legend of our race."--The Chamber of Commerce Journal.

"A book such as that presented by C. Y. C. Dawbarn under the title of 'Liberty and Progress' is well worthy of perusal by men of all shades of opinion. It places under review many of the problems that are at the present time exercising the minds of the public, and about which much is being uttered that is born of a lack of knowledge. . . . 'No reforms,' writes the author, 'are practicable which invade the fundamental condition of our lifo, our personal liberty' and his endeavour throughout the book has been

D. 
to show the truth of this doctrine. Much of what Mr. Dawbarn says is not new, but he has placed the matter before the reader in a manner that may be well calculated to help those who wish to give such subjects as are dealt with in this volume serious and impartial consideration."-The Field.

"This is an interesting and well-reasoned exposition of the conditions of labour and wealth in the modem body politic. Mr. Dawbarn deals with his subject under three heads-The Employed, the Principles of Employment, and Our Underpaid and Unemployed. $\mathrm{He}$ is an Individualist of a sane type, and he is a Benthamite of a rather idolatrous kind. I am sorry that the price is so prohibitive, as. I am convinced that nothing but grood conld result from the reading of this volume. The putting of the principles of Political Economy is so clear, and, even where one cannot agree with the writer, the argument is so restrained and fair, that I should advise my readers to look ont for the book in the libraries and get it. It will help to clear a good many hazy notions and organise much chaos."-The Young Man.

"This is a powerful and arresting book, written by an earnest student of the deepest problems of economic and social science. It is the product of strenuous and fearless thought, and is certain to stimulate the speculations of others and to provoke fertile discussion. There is not, perhaps, in any one chapter much that is not already known to students who have specialised in the various subjects there discussed. Yot the book taken as a whole is original in the best sense of that often misunderstood word. Mr. Dawbarn has made his own selection of his materials, marshalled them in his own order, recreated the whole in passing through lis own mind, and formed his own conclusions. He has written a book not perhaps for professors and learned pedants, certainly not for shallow people who shirk the labour implied in ordered thought, but for the great mass of the intelligent general public who are anxious for guidance on the deeper problems of economic and political science-problems which they feel mnable to probe to the boitom for themselves. Mr. Dawbarn's fair-minded and lucid arguments cannot indeed be followed without some effort --inseparable from the fundamental nature of the phenomena discussed; but his treatise is well worth the time and labour required for mastering its con!ents. . . . Mr. Dawbarn is an Individualist and a modern Benthamite; and we recommend his book not because we agrea writh his conclusions (which wo by no means always do) but because its perusal by thoughtful readers of all types, whether Socialists or Individualists, Radi- 
cals or Reactionaries, will help to elear their minds from fallacies and enable them to approximate more nearly to the truth. .. . If philosophy really means, in Hegel's phrase, 'the thinking things together,' Mr. Dawbarn's successful attempt to focus a wide field in a small lens entitles him to rank as a philosopher-of the practical, useful type. His thoughtful book cannot be too widely read."-Glasgow Herald.

"Individualism in economic theory is so generally taken for granted that there sems a certain element of novelty in a treatise which explicitly inculeates it as Mr. Dawbarn's readable work does: The book is really an essay in political ceonomy. Without being systematic on academic lines or exhaustive of the topics generally dealt with by scientific economists, it discourses thoughtfully and suggestively about wealth, prices, and values, and about the nature, the incidents, and the limitations of property. . . . It is true throughout to recognized and now well threshed out principles of individualism, and the author may be said, figuratively speaking, to swear by Jeremy Bentham. There is so much running counter to all this in the most conspicuous economic literature of the day that the work cannot but prove acceptable to many reader's who will resognise both the older doctrines themselves and the froshness which they gain from Mr. Dawbarn's temperate and well reasoned re-statement."The Scotsman.

"Learning without thought is learning lost, thought without learning is perilous. It will be remembered that $\mathrm{Mr}$. Dawbarn was the Liberal eandidate for the Ormskirk Division at the last general election [1906], and is therefore well known to most of our readers. But having so far identified the anthor, we must at onee disclaim any wish to associate political bias in the work under notice. It is one wo cordially commend to thoughtful readers, and to those who are not led by the nose by partisan or prejudiced leaders. It is a book for study rather than easual reading. The author claims that 'no new gospel is preached, no new suggestion made'; but the application of old prineiples to new conditions, and the fair and impartial ascertainment of what those new conditions are which should be modified or amended. . . The conclusion arrived at is that progress does not depend upon any brilliant new departure, still less on any violent social upheaval; but on an exact knowledge of existing conditions, their relation one to another, and a tentative advance of one step at a time. . . We strongly recommend a study of this more than ordinary work." -Ormskirk Advertiser.

"The publication at the present moment of Mr. C. I. C. к 2 
Dawbarn's book, 'Liberty and Progress,' is singularly appropriate. Bentham's philosophy, profoundly affected the legislarion of the latter half of the nineteenth century, and though the modern 'Reformer' affects to despise the teaching's of the old rutilitarian Radieals as out of date while unquestionably they ignored features of the problem that have a vital bearing upon the issue, it would undoubtedly be better for the State if some of our present-day legislators had more of the ability, the unselfishmess, and the public spirit which distinguished Bentham and his disciples. In Bentham's day the head was perhaps too much in evidence and the heart too little; to-day the exact reverse is true. In the attempt to satisfy our emotions, the warnings of the head and the teachings of experience are alike in danger of being neglected. The volume before us will do something to eheck the tendency. 'To-day,' says the author, "the air is full of reforms-well-considered reforms, ill-considered reforms, and reforms not considered at all. Their variety is legion, their qualities as varied, but all have one common characteristic, the spending of more money-other people's money-and, as an inspiration, it might be suggested that the greatest and most wanted reform of all is to reflect more and scatter less.' . . Existing evils, he continues, are neither to be eradicated nor cured by an ill-considered raging at our present social system generally or by making a clean sweep of every existing institution. . . . The social questions touched upon in this volume are not to be solved by mere syllogisms, but it is very necessary that the emotional socialism of the day should be corrected by the hard-headed reasonings of men like Mr. Ditwbarn. For this reason we heartily weleome the volume before us."The Blackburn Times.

"The theoretical part of Mr. Dawbarn's book is devoted to proving that an individualistic State affords the only possible way to real progress for a liberty-loving people like the British; that any interference with the free play of competition in the supposed interests of the poorer classes and the unemployed is liable to aggravaie the evils it is intended to cure by artificially perpetuating the unfit and increasing their number. Hard logie on these lines would seem to lead to the conchusion that nothing an be or ought to be done for the submerecel, who are to be lefi for Nature to deal with as she deals with surplus progeny in the struggle from which only the fittest emerge. Mr. Dawbarn, however, refuses to be driven so filr when he comes to consider the practical side of the question, and he admits that for humanity's sake something munst be done; and though he will not allow that the State is 
bound to provide work and relief, to be demanded as a matter of right, he thinks that it may and should do something as a matter of expediency and compassion. Thus he is in favour of legislative action on behalf of the underpaid. While the State cannot be ealled upon to find work for the unemployed, it ought (he contends) to see that justice is done to those who do work, and he is quite prepared tor a legal enactment fixing. a minimum wage rate for the lower grades of labour. If anything of the kind is done, however, it should be accompanied by 'precautions for such extra wage being' spent in desirahle ways,' and in this comnection he adrocates the enforcement of measures against overcrowding, as well as efforts to edncate the people up to a better recognition of the need of thrift and of their responsibilities as parents.

At the other end of the scale he would also deal with the overpaid, i.e., those who prey on society by extorting more than a just reward for their services. . . .

Mr. Dawbarn points out; however, that it by no means follows that big earnings are necessarily any proot of unfair practices, and it is fair to him to say that he has no sympathy with the ignorant prejudice against capital as such. Indeed he deprecates attacks on property as against the interest of the State as a whole, and especially of the working classes. . . .

If the underpaid workers have a right to claim that the State shall see justice done to them, what are the rights of the unemployed? They have no rights, says Mr. Dawbarn. "They give no services, they are entitled to nothing in return.' This understood, the ground is cleared.

'The foundation of individualistic society is pure selfishness to give, to realise as much again. If this priuciple is recognised, then with less danger and more benefit can we give effect to the altruistic emotions which so extensively govern human atfairs. ...'

What, then, can be done for the unemployed? Mr. Dawbarn insists that first, as for the underpaid, nothing would prove one-half as beneficial as enforcing the doctrine of parental r'esponsibility.

"The country could be metamorphosed by the effective treatment of one generation, and so-ealled cruelty to the improvident of to-day might result in a chorus of thanksgiving in untold years to come. . . .'

Emigration is put aside as a possible remedy-it learos tho unfit at home still to be dealt with.

- We are driven back to our original position, that there is only one way of inproving our country as a whole, viz., by making the individual a better, more independent, and more responsible person.' 
This, says Mr. Dawbarn, does suggest one possible reform -we might eheck the manufacture of the unemployed by taking hold of lads who have left school and can get no work, and placing them in a military sehool where they would be taught a trade and be turned out fit and strong at twenty-one. For the general body of the unemployed, what is wanted is a system which will help the deserving to gravitate back into the ranks from which they have dropped out, and deal with the remnant in such a way as to be the least possible burden on the community. Mr. Dawbarn advocates the consolidation of the poor-laws, the co-ordination of public and private charities, and effective difiecentiation of the assisted...."-Nottingham Guardian Literary Supplement.

". . . . Mr. Dawbarn is, like Spencer, an individualist. He dislikes State eontrol, particularly bureaueratie control, as an encroachment upon liberty. It is better, in his view, to have liberty to make mistakes than to be shepherded through life by superior intelligenee, to the loss of sturdy independence and power of initiative. He is insistent, too, on the prineiple that there should always be a well-defined line between what a man can expeet as of right and what he can ask only as of charity. The corollary, of course, is that 'reforms ' whieh depend upon taxation (i.e., the taking and spending of other people's money) are necessarily suspect; and the defence of the rights of property necessary to support this position is worked out with candour and aeuteness. It is, of course, quite impossible to avoid asking the question: Would civilisation have gone on so fast, would the general conditions of life in England have improved so rapidly, if the State laad steadily adhered to Mr. Dawbarn's principles? . . . . Nevertheless, his book, as we have said, is candid, logieal, and extremely suggestive."-The Birmingham Daily Post.

"In these days it is refreshing to encounter a stout individualist, to listen to the roies which has the courage to tell us that there is little wrong with the social fabric if only men will leave it alone. Possibly the one pleasant doctrine whieh the nineteenth century did manage to establish was that a man should be at perfect liberty to play ducks and drakes with his life after his own fashion. That particular conception our age is doing all it can to overthrow. Perhaps it is well; but who shall decidle?

It will have been inferred that Mr. Dawbarn is an Individualist. One class in society - the swexted-he exempts from the operation of the law of self-interest. It looks, indeed, like the thin end of the wedge, but he manages to justify his attitude. Of course, no man, not even Ricardo, hoped or wished 
for a social structure entirely individualistic. It is largely a question of emphasis. The one group of thinkers lay the stress on the efforts of the individual; the other on the intervention of the body politic; but neither dreams of pushing its views to their logical conclusion, which is well. After all, logie never built a human society. Individualism, with all its faults, always predicates the existenee of altruism, not, truly, as a part of itself, but as a force which in other spheres operates just as strongly as self-interest in the economic. Says Mr. Dawbarn, "they are distinct, and the complement the one of the other; and whilst in a well-ordered state both are present and both essential, both also are more vigorous and more effective when the dividing line between the two is weli maintained.' . . The treatment of property on the lines laid down by Bentham is excellent. But this, of course, is purely a political question in the broadest sense of the term. None the less the remarks on the subject, in the light of recent proposals, are extremely apposite. The venerable Jeremy was always pretty strenuous in rebutting attacks upon land. And Mr. Dawbarn takes up the argument from him. Multis minatur, qui uni facit injuriam. Touch one form of property and all are in danger. Governments and peoples are like tamed lions; 'Let them but taste a drop of blood and their native ferocity revires.' So nations in attacking property hark back to the primitive ages in which the rights of the strong arm were alone respected. 'Poverty,' says the author, 'is not due to other's wealth-its alleviation is.' Besides, to attack one section of the wealthy does not remove the anomaly if it exists. It was Burke who observed that "those who attempt to lovel never equalise." -. Liverpool Courier.

"This book is a statement and a vindication of that individualism upon which the whole fabric of Western civilisation is founded. Clearly and simply. with marvellous freedom from technicalities Mr. Dawbarn states his case, and his arguments deserve the consideration of every man of open mind who is concerned with the relationship of capital and labour. It is difficult to indicate the scope of the book in few lines, so full are the pages of suggestive ideas, but the root prineiple is the absolute dependence of labour upon capital, the importance to labour of cheap capital, and the impossibility of procuring cheap capital without security. "Where property, as property, is safe and fully protected by the law, where its possession is oncouraged, there it is most freely put on the market at the lowest rate.' On the other hand, 'where security is barl, as in some Oriental eountries, not eren 50 per" 
cent. will tempt the owner to part with its possession,' and from want of security some of the richest parts of the world have sunk into beggary. Taking some figures compiled ly Mr. Chiozza Money, Mr. Dawbarn shows how enormously the position of the working classes has improved during the last century, and how entirely the improvement is due to capital. 'Poverty is not the work of the laws; it is the primitive condition of the human race,' and that we are no longer homeless savages is due to the effort and self-denial-all thrift is self-denial-of individuals who, sacrificing immediate pleasures, accumulated capital, and in benefiting themselves benefited the community by its employment. But without security of possession these individualists would have had no encouragement to save, or saving would not have dared to employ their capital, and to-day, as at all periods of history, the greatest injury to the worker is done by wanton attacks on property, and the loss of confidence which inevitably follows. Irresponsible and munecessary interference with property is, indeed, 'little short of criminal, because of the misery it causes.' With a wealth of illustrative facts and figures Mr. Dawbarn drives home his arguments, and very rarely has political economy been made so pleasant and attractive."-Manchester Courier. 


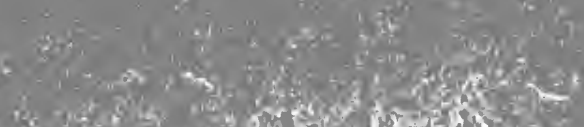

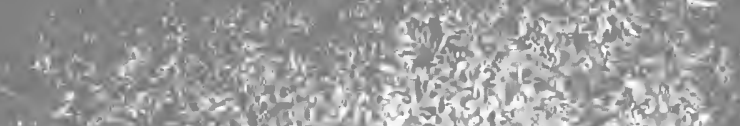

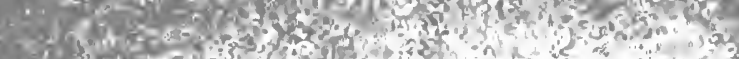

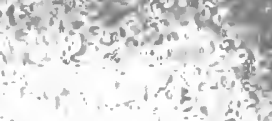

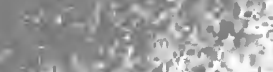

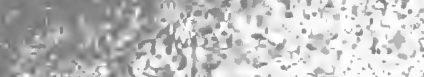

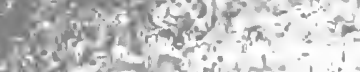

10.

tots

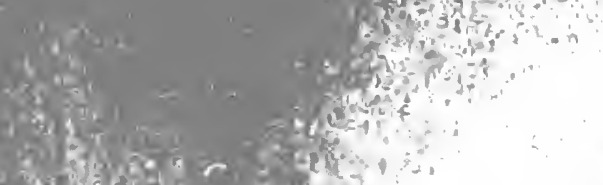

a.s.

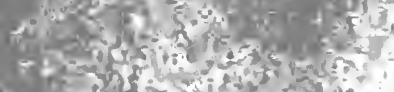

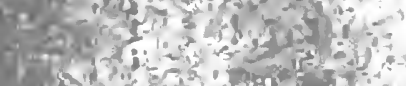
Q

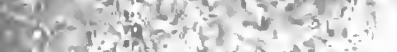
w. Lin

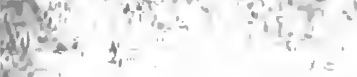
Q:-

$-$

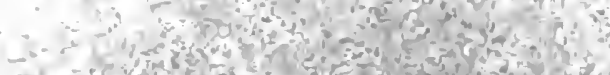

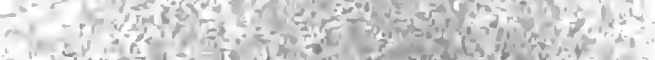

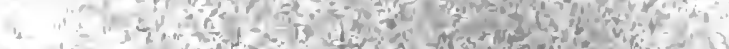

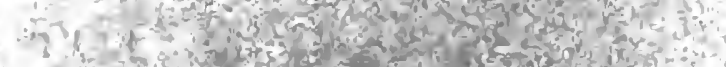

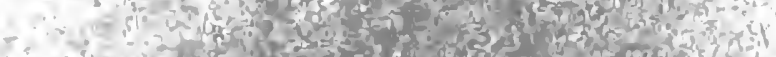

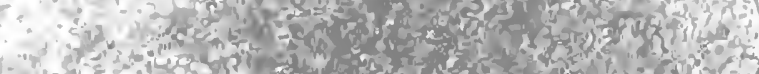
$\therefore=1$ a

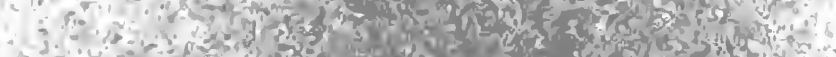

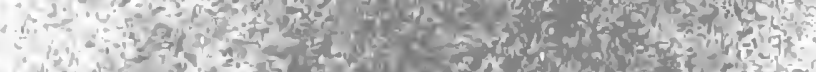
a

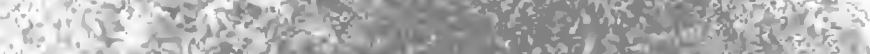
\%

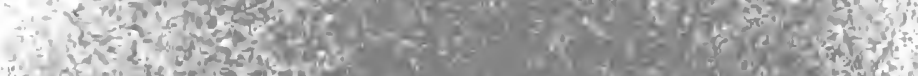

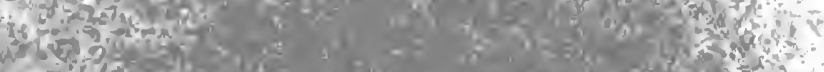

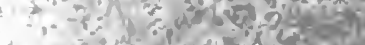

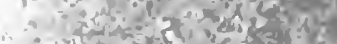

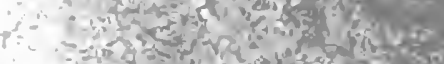

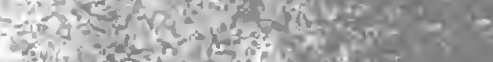

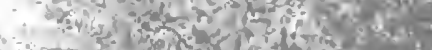

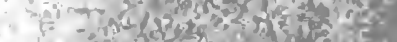

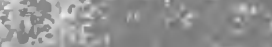

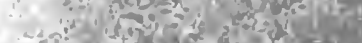
सin: की nowis?

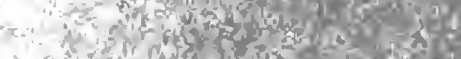
3.x.

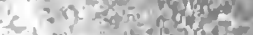

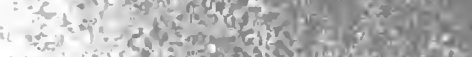

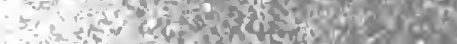

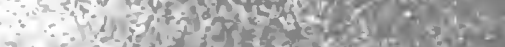

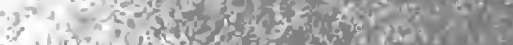

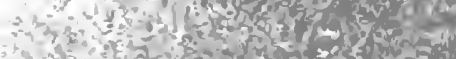

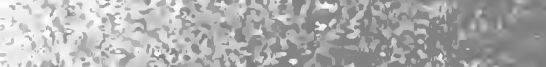
in

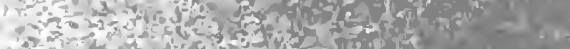

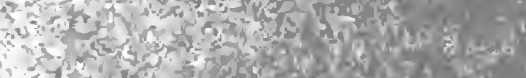

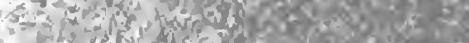

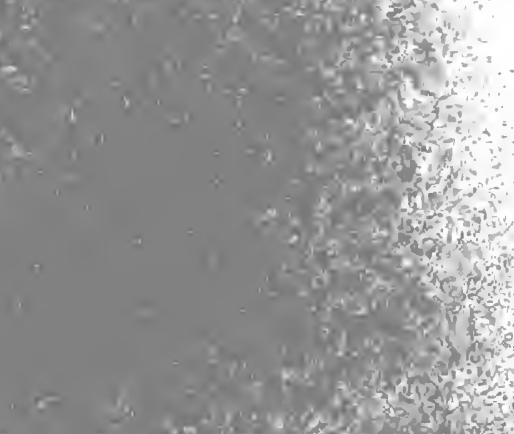
s.

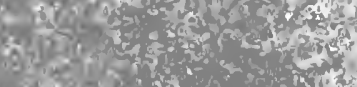

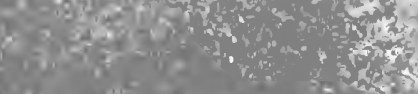
$\sin ^{2} x^{2}=$

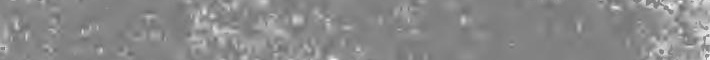

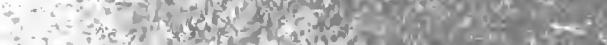




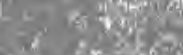

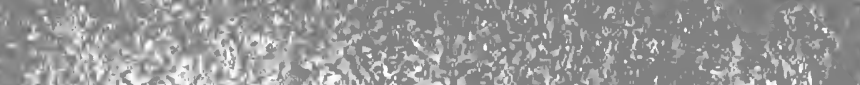

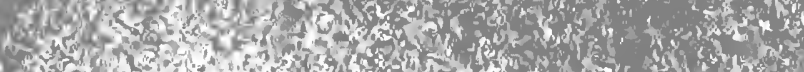

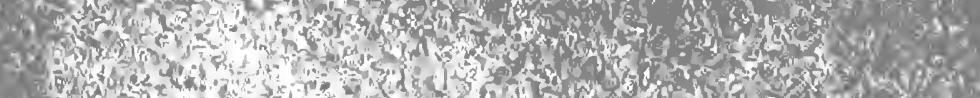

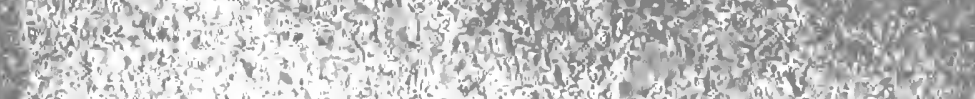

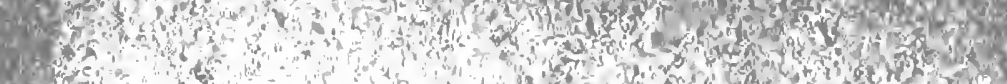

sornots $x$ 3 n . n
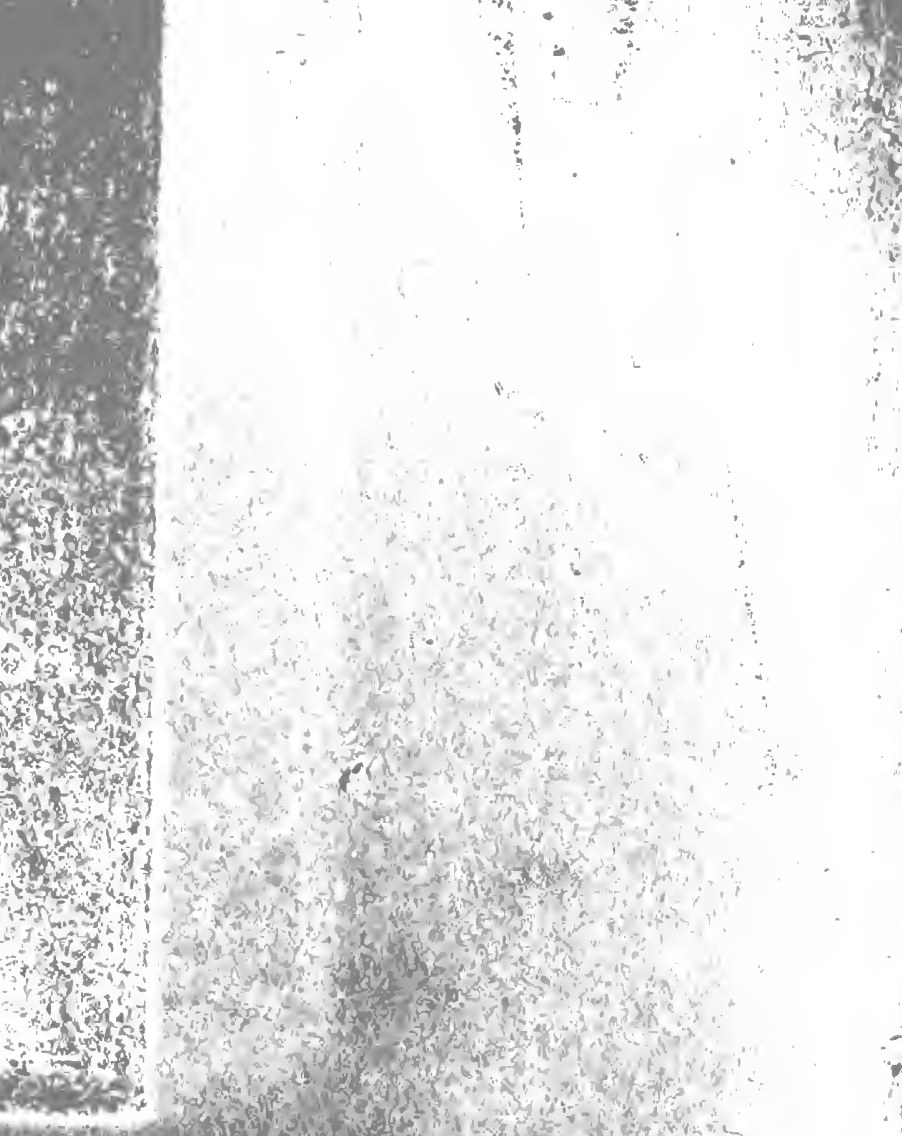

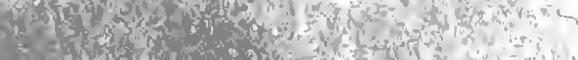




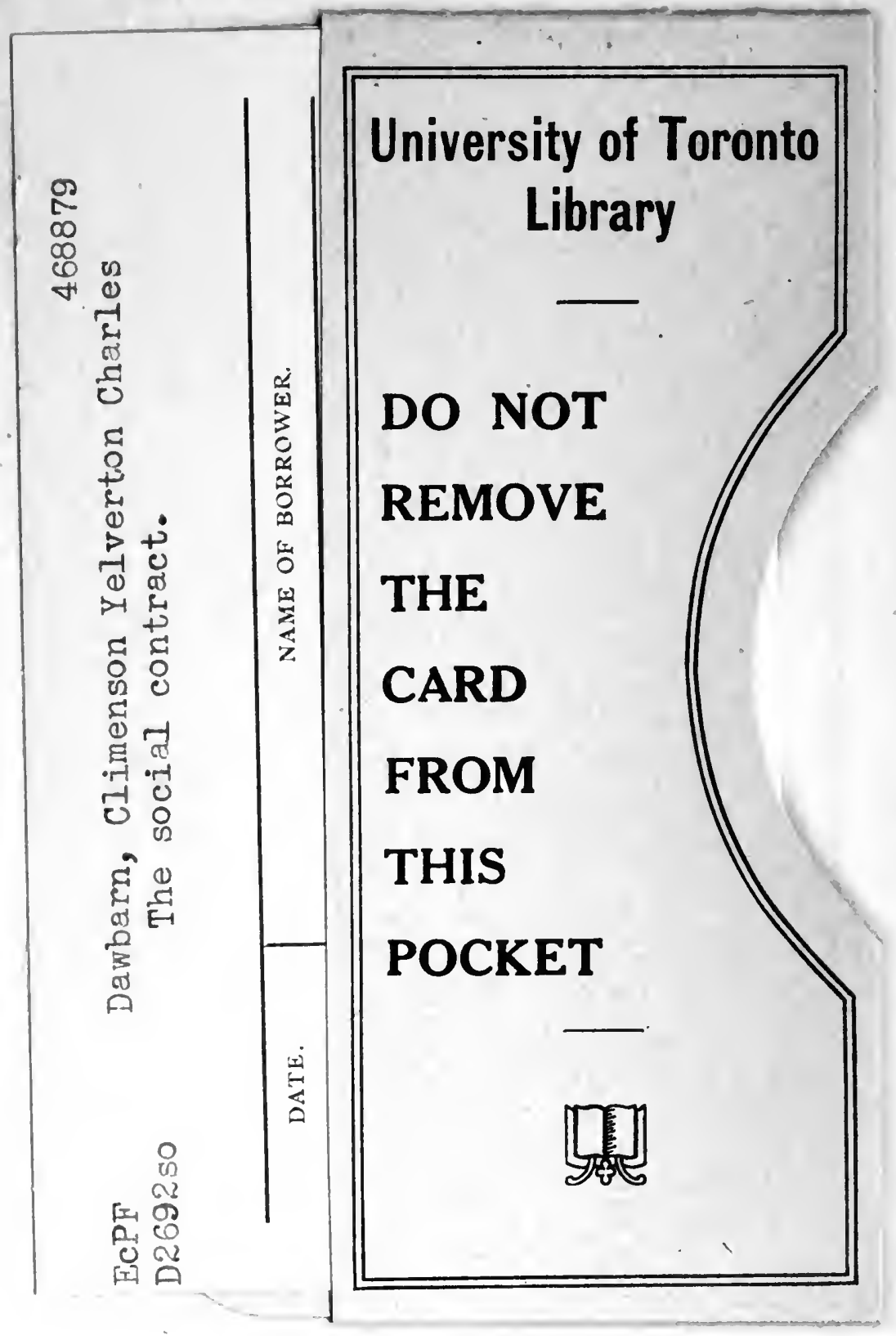


